\title{
GCU
}

Glasgow Caledonian

University

University for the Common Good

\section{Credit rating, banks' capital structure and speed of adjustment: a cross-country analysis}

Wojewodzki, Michal; Boateng, Agyenim; Brahma, Sanjukta

Published in:

Journal of International Financial Markets, Institutions and Money

DOI:

10.1016/j.intfin.2020.101260

Publication date:

2020

Document Version

Author accepted manuscript

Link to publication in ResearchOnline

Citation for published version (Harvard):

Wojewodzki, M, Boateng, A \& Brahma, S 2020, 'Credit rating, banks' capital structure and speed of adjustment: a cross-country analysis', Journal of International Financial Markets, Institutions and Money, vol. 69, 101260. https://doi.org/10.1016/j.intfin.2020.101260

\section{General rights}

Copyright and moral rights for the publications made accessible in the public portal are retained by the authors and/or other copyright owners and it is a condition of accessing publications that users recognise and abide by the legal requirements associated with these rights.

Take down policy

If you believe that this document breaches copyright please view our takedown policy at https://edshare.gcu.ac.uk/id/eprint/5179 for details of how to contact us. 
Credit Rating, Banks' Capital Structure and Speed of Adjustment: A Cross-Country Analysis

\begin{abstract}
Recent studies examining the effects of a credit rating on firms' capital structure and adjustment of capital structure to target have focused predominantly on non-financial firms, with virtually no attention given to financial institutions. Using an international sample of 391 rated banks from 76 countries, this study examines the effects of credit ratings on the capital structure of banks. We find that, on average, banks near a credit rating upgrade have a higher capital to assets ratio compared to banks not near a rating upgrade. Most systematically important "too-big-to-fail" banks near a credit rating upgrade tend to have lower capital relative to assets than the rest of the banks in our sample. Furthermore, banks downgraded from an investment-grade rating to a speculative-grade rating, on average, hold 1 (3) percentage points less capital relative to assets in the short (long) run. Contrary to studies based on non-financial firms, our results show that credit ratings have relatively little economic effect on the speed at which banks' capital is adjusted. Our results suggest that while rating agencies exert influences on banks' capital structure, they are fewer in number and tend to be weaker, compared to those documented in non-financial firms.
\end{abstract}

JEL classification: G21, G24, G28, G32

Keywords: Bank Ratings; Capital ratio; Speed of adjustment

Declarations of interest: none

Funding: This research did not receive any specific grant from funding agencies in the public, commercial or not-for-profit sectors. 


\section{Introduction}

Massive downgrading carried out by credit rating agencies during and after the 2007-2009 financial crisis led many observers, regulators and policymakers to conclude that unjustifiable credit ratings (relative to the default risk) were one of the primary factors that contributed to the global financial crisis (Baghai et al., 2014; Griffin and Tang, 2011). Research evidence indicates that many undercapitalized banks, such as Lehman Brothers, enjoyed inflated, investment-grade credit ratings due to methodological errors and conflict of interest situations, only weeks before defaulting (Hau et al., 2013). It is therefore not surprising that credit rating agencies have become the focus of scholarly attention and scrutiny by academics, policymakers and regulators ${ }^{1}$ over the past ten years (Baghai et al., 2014; European Parliament, 2009; European Securities Market Expert Group, 2008; Financial Services Authority, 2009). However, prior empirical efforts have focused mostly on the role and regulatory reforms of credit rating agencies (Deb et al., 2011; White, 2019) and the associations between credit ratings and the capital structure of non-financial companies (Kisgen, 2006; 2009; 2019; Wojewodzki et al., 2018). Virtually no attention has been given to financial institutions, as far as we are aware.

Against this backdrop, this study builds on the prior literature by analyzing the associations between credit ratings and capital structure in the banking industry and banks’ adjustments to target capital structure. The examination of the relationships between credit ratings and banks' capital structure in a cross-country context is timely and important for banks' profitability, stability, and regulation for the following reasons. First, the assets and liabilities of banks (e.g., deposits and loans) are fundamentally different from those of non-financial firms (Fan et al.,

\footnotetext{
1 In February 2009, the European Commission issued a report on the future of European financial regulation and supervision. In March 2009, the U.K.'s Financial Services Authority published the Turner Review on the responsibility of credit rating agencies in its analysis of the causes of the financial crisis.
} 
2012), and information embedded in a credit rating constitutes a basis of customers' trust and confidence in the quality of a bank's assets, which is important for bank stability (Millon and Thakor, 1985). Second, several regulations relating to banks’ capital and investments in bonds are directly tied to credit ratings, thereby underscoring the importance of ratings to banks' profitability and stability (Kisgen, 2019). Indeed, Kisgen (2006) aptly notes that financial regulators rely on credit ratings and rating levels to decide whether to allow particular investor groups, such as banks, to invest in other banks' bonds and to what extent investor groups meet specific capital requirements when lending to other banks. Third, new capital regulation (Basel III) enjoins banks to have at least 3\% of capital relative to their total assets. This new leverage ratio requirement coincides with the Lehman Brothers' ratio in its last statement of financial position before it went bankrupt (Admati and Hellwig, 2019). Thus, it enables internationally active banks, which are now more systemically important and larger than before the 2007-2009 crisis, to hold alarmingly low capital levels. Importantly, systematic research documents substantial disparities in the speed of adjustment of banks' capital, and the results thus far appear mixed and inconclusive (De Jonghe and Öztekin, 2015; Memmel and Raupach, 2010). Lastly, unlike non-financial firms, banks routinely borrow from and lend to one another in wholesale markets. Consequently, the importance of credit ratings in the context of banks' costs of borrowing stems from capital adequacy requirements imposed on banks through the first pillar of Basel Capital Accord II and III. For instance, credit ratings are used to determine risk weights assigned to banks' assets, which in turn determine capital charges. $^{2}$

Our study makes four new primary contributions to the literature on banks’ capital structure using a cross-country framework. First, we document that while rating agencies influence

\footnotetext{
${ }^{2}$ Credit ratings are used directly under the so-called "standardised approach" and serve as a benchmark in the so-called “internal ratings-based approach".
} 
banks' capital structure, the agencies are less significant compared with non-financial firms. For instance, we test seven credit rating effects previously established in studies relating to non-financial firms and find only two of these to be statistically significant for banks. More specifically, we document a positive “plus sign” effect, i.e., banks near a credit rating upgrade have higher capital to assets ratio compared to banks not near a rating upgrade. Interestingly, the "plus sign" effect turns negative and increases in magnitude for the most systemically important cohort of banks. Such results indicate that, on the one hand, the expected future gains stemming from the rating upgrade (e.g., cheaper and easier access to debt) are large enough for the majority of sampled banks (less systemically important) to bear the costs of increasing their capital. On the other hand, the most systematically important "too-big-to-fail" banks use a positive signal of being near the rating upgrade to further reduce their already low capital ratios. Moreover, we observe a negative “fallen angel” effect, i.e., banks downgraded from an investment-grade rating to a speculative-grade rating (fallen angels), on average, hold about 1 (3.2) percentage points less capital relative to assets in the short (long) run. In contrast with studies on non-financial firms, we find evidence of only a miniscule economic effect of credit ratings on the speed at which banks' capital is adjusted. Hence, credit ratings appear not to be responsible for the widely different speeds of banks' capital structure adjustment documented in prior studies. Lastly, we test Kisgen's Credit-Rating Capital Structure (thereafter $C R-C S$ ) hypothesis ${ }^{3}$ for the first time using a model of banks' capital. Our findings suggest that no single theory of capital structure can explain the associations between credit ratings and banks' capital ratio. Lastly, we contribute to the ongoing debate on the effectiveness of capital regulation in the banking sector. Specifically, the results that long-run "plus-sign" and "fallen angel" effects of approximately 1 and 3.2 percentage points,

\footnotetext{
${ }^{3}$ Kisgen (2006) lays out his influential CR-CS hypothesis, where costs and benefits of credit ratings have enough power to trigger changes in firms' capital structure policies, at odds with both the pecking order theory and the trade-off theory.
} 
respectively, suggest that the $3 \%$ minimum leverage ratio recently set in the Basel III Accord is not adequate. As such, our study adds to the existing choir of prominent voices in academia advocating for a drastic increase in banks' equity levels and the leverage ratio introduced in Basel III. Therefore, our findings imply the need to strengthen the regulatory capital requirements for banks.

The remainder of the paper is structured as follows. Section 2 reviews the literature, while Section 3 develops the hypotheses of the study. Following that, Section 4 offers a description of the data sources, sample, measurement of variables and econometric model employed. We present empirical results and discuss them in Section 5. Section 6 outlines a battery of robustness and sensitivity tests conducted. Finally, Section 7 provides the conclusion and discusses the implications and limitations of the paper.

\section{Literature Review}

Credit ratings, which constitute a proxy for the probability of default, ${ }^{4}$ play an important role in financial markets across the globe. It is argued that credit ratings enable markets and investors to set the required rate of return, in line with the level of default risk carried by the rated entity/financial security (Ferri et al., 1999). Consequently, credit ratings affect the access to and costs of borrowed funds. Moreover, the better the credit rating, the stronger the marketability of the financial obligation (e.g., a corporate bond) assessed by a credit rating agency. Others contend that credit ratings reduce asymmetric information and improve market discipline by providing valuable information to market participants (Kolaric et al., 2019). In addition, credit rating agencies fulfil a quasi-regulatory function (Deb et al., 2011; White, 2019). It is against this backdrop that credit ratings issued by the "Big Three" credit rating

\footnotetext{
${ }^{4}$ According to Ferri et al. (1999) the higher the assigned credit rating, the lower the default risk and the greater the likelihood of timely repayments by a rated borrower.
} 
agencies (S\&P, Moody’s and Fitch) have been embedded into international regulation on capital requirements for banks in Basel Accords: Basel II and, to a smaller extent, Basel III. In the survey of factors affecting the desired amount of debt, Graham and Harvey (2001) document that credit rating is second in importance to the CFOs of U.S. firms. The authors find that over $57 \%$ of 392 surveyed managers regard their firms' credit ratings as "important" or "very important” in deciding firms' level of debt. Indeed, evidence from other research surveys suggests that managers appear to consider credit ratings when making capital structure decisions. For example, Servaes and Tufano (2006), in a worldwide survey of 334 CFOs, document that $60 \%$ of firms do not add more debt because they have reached their target and such addition would lead to a drop in credit ratings. Such findings support the contention that credit ratings are important in a firm's capital structure decisions.

Against a backdrop of perceptions and anecdotal evidence, Kisgen (2006) made the first attempt to examine the association between credit ratings and capital structure. In his influential article, Kisgen (2006) proposes the CR-CS hypothesis, asserting that credit ratings are a material consideration in capital structure decisions due to the discrete costs and benefits associated with different levels of credit ratings. Kisgen (2009) shows that downgraded firms adjust their leverage towards target levels more rapidly, whereas rating upgrades have no statistically significant bearing on firms' speed of adjustment. More recently, several studies, such as Gu et al. (2018), Huang and Shen (2015) and Wojewodzki et al. (2018), have attempted to examine the influences of credit ratings on capital structure decisions in international context. For example, Huang and Shen (2015) render support for the findings of Kisgen (2009), indicating that downgraded firms react by decreasing their debt levels, whereas there is no corresponding effect for upgraded firms. In their cross-country study, Wojewodzki et al. (2018) document that credit ratings' effect on firms' leverage ratios is 
negative and becomes more significant the more market-based the financial system of the country in which firms operate. Furthermore, the authors observe that the lower the credit ratings, the faster the speed of adjustment.

While the studies of Huang and Shen (2015), Kisgen (2006, 2009) and Wojewodzki et al. (2018) have made notable contributions to the literature, it is pertinent to note that these studies focus on non-financial firms. However, as pointed out earlier, financial firms are different from banks in terms of their assets, liabilities and how they are regulated with implications for credit access, costs, and profitability. This study, therefore, extends our understanding of the relationship between credit ratings and the capital structure choices of banks which were at the heart of the global financial crisis of 2007-2009. It is therefore imperative that we examine the effects of credit ratings on banks' capital structure decisions in a worldwide context, and how capital structure adjusts to target levels.

\section{Hypotheses Development}

The effects of credit ratings on capital structure decisions have been examined and explained from several theoretical standpoints, including trade-off theory and pecking order theory. On the one hand, the trade-off theory suggests a positive relationship between credit rating levels and a rated firm's level of debt. Indeed, Kisgen (2009) finds a positive association between credit ratings levels and firms' leverage and explains that credit ratings may serve as a signal of a firm's overall quality. This is because credit ratings offer rated firms enhanced access to capital markets and a cheaper cost of borrowed funds (Gu et al., 2018; Kisgen and Strahan, 2010; Sufi, 2009). For example, Kisgen and Strahan (2010) find that "a firm losing its investment grade would suffer a larger increase in its cost of capital than would be expected solely from the implied increase in probability of distress.” (p.4345). 
On the other hand, the pecking order theory suggests a negative relationship between credit ratings and firms' financial leverage. Grounded in the above, Frank and Goyal (2009) and Liu and Malatesta (2005) argue that better credit ratings convey signals of firms' value while decreasing the degree of information asymmetry that exists between managers of rated firms and stock market investors. Consequently, Frank and Goyal (2009) and Liu and Malatesta (2005) contend that by reducing the information gap, more highly rated firms should experience lower costs of equity financing and are more likely to issue equity over debt.

Moreover, other studies on the effects of credit ratings on non-financial firms' capital structure (Kisgen, 2009; Samaniego-Medina and di Pietro, 2019; Wojewodzki et al., 2018) highlight the importance of borderline (between investment and non-investment grade) credit ratings on capital structure. This is due to regulatory restrictions imposed on institutional investors in the U.S. and other countries (Kisgen, 2019), thereby negatively affecting non-investment grade firms’ costs of external finance and pool of investors.

Prior research (e.g., Fan et al., 2012) indicates that liabilities, assets, and the composition of banks' capital structure are fundamentally different from those of non-financial firms. Diamond and Rajan (2000) highlight unique functions performed by commercial banks in an economy, such as liquidity and credit provision in the form of issued deposits and loans. Due to the costs of financial distress, it is unusual for non-financial entities to have more than $75 \%$ of assets funded with debt. However, banks often possess $95 \%$ or more of debt relative to assets. Such disparity between banks and non-financial firms occurs despite no regulation forbidding the latter from borrowing as much as desired, while capital regulation is imposed on banks. Moreover, it appears common for banks with 5\% or less of capital to total assets to 
engage in dividends payouts, equity buybacks and, whenever possible, adding more debt (Admati and Hellwig, 2019). Admati et al. (2018) call such pervasive addiction to debt the "leverage ratchet effect" 5 and argue that it is tolerated, enabled and even encouraged by explicit and implicit government guarantees, subsidies and the passivity of banks' creditors.

We argue that if there is an association between credit rating levels and banks' capital ratio, it should be negative. Our expectation stems from credit ratings' regulatory hardwiring giving a rise to so-called certification function of ratings. This, in turn, might further magnify credit ratings' influence on cost, and the accessibility of debt financing documented by empirical studies (see e.g., Adelino and Ferreira, 2016; Crabbe and Post, 1994; Flannery and Sorescu, 1996; Sironi, 2003). Thus, banks are expected to capitalize on better credit ratings, by increasing borrowing to facilitate more lending, leading to an expansion in banks' total assets, and a decrease in capital ratios ${ }^{6}$. Furthermore, safety nets and guarantees offered to banks and their creditors motivate managers and shareholders to borrow more at a low cost (leverage ratchet effect) when given the opportunity to inflate their assets side of the balance sheets, leading to a sought-after increase in the ROE ratio. This takes us to our first hypothesis.

Hypothesis 1. Credit rating levels are negatively associated with banks' capital ratios.

Kisgen (2009) investigates firms’ financing mix in the aftermath of announced changes in credit ratings and finds evidence that $40 \%$ of firms are more likely to refrain from issuing debt, while $85 \%$ are more likely to decrease their debt levels after being downgraded. However,

\footnotetext{
${ }^{5}$ In a study devoted to the "leverage ratchet effect", Admati et al. (2018) point out that banks' shareholders routinely oppose any decreases in leverage, even if such decreases would mean an increase in a bank's value. Instead, shareholders push for an increase in banks' leverage, even if this means a reduction in the bank's value.

${ }^{6}$ This is, under a plausible assumption of no simultaneous increase in banks' equity offsetting the increase in banks' total assets. In fact, Figure 3 on page 30, delivers an initial support of such behaviour, by showing that, on average, banks with the highest credit ratings have the largest total assets but the lowest capital ratios.
} 
Kisgen (2009) documents that the reaction to rating changes is asymmetric, i.e., firms' equity and debt issuance are not associated with credit rating upgrades. He argues that such asymmetricity corresponds with anecdotal evidence of companies' efforts to maintain their target (minimum) credit ratings. ${ }^{7}$

Tang (2009) observes that firms with refinement upgrades (e.g., from Baa to Baa1), enjoy cheaper costs of borrowing, gain easier access to credit markets and are much more likely to increase their debt versus equity. The opposite effect is found with regards to firms with refinement downgrades. Maung and Chowdhury (2014) document that, as a follow-up to being downgraded, non-financial firms are much more likely to reduce their debt. However, contrary to Kisgen (2009), they also find evidence of a positive association between credit rating upgrades and firms’ debt. Huang and Shen (2015) revalidate Kisgen’s (2009) findings on the asymmetric association between rating changes and firms' capital structure. Wojewodzki et al. (2018) reported symmetrical behaviour of firms’ leverage one year after changes in ratings.

Research evidence suggests that banks also might have rating targets. Adrian and Shin (2010) observe constant credit ratings in a sample of U.S. banks. Iwarere and Akinleye (2010) document that for the CFOs of 25 Nigerian banks, a credit rating is one of the most important factors when deciding on the amount of debt in the capital structure. Schweitzer et al. (1992) observe that the information value of rating downgrades (proxied by the abnormal negative returns on a stock price) is larger than that of non-financial firms. To Jackson et al. (1999), a targeted credit rating is one of the reasons why banks hold additional capital to satisfy credit

\footnotetext{
7 There is ample anecdotal evidence indicating that rated firms have credit rating minimum targets, e.g., In July 2009, British corporate RELX plc, striving to protect a BBB+ investment-grade rating, issued GBP 824 million in shares (Costello and Sabbagh, 2009).
} 
rating agencies. Indeed, at the inception of Basel II Capital Accord, the external credit ratings are considered when determining the level of capital that banks are required to hold with regards to their risk-weighted assets. Memmel and Raupach (2010) refer to rating agencies' regulatory powers as one of the potential factors that may push banks to hold more capital than otherwise intended. Given the hardwiring of credit ratings into banking regulations (e.g., Deb et al., 2011; White, 2019) it is argued that changes to a credit rating should be associated with banks’ capital ratios.

Admati and Hellwig (2019) assert that banks' addiction to borrowing and allergy to capital financing, makes them particularly prone to the "leverage ratchet effect". Adelino and Ferreira (2016) document that banks' credit ratings downgrades are associated with a significant increase (decrease) in cost of (access to) banks' long-term (short-term interbank) borrowing, and a substantial reduction in banks' lending. Hence, it is expected that, as a follow-up to being upgraded (downgraded), managers take the opportunity (are forced) to lever up (un-lever) their capital structure. In line with the above argument, Maung and Chowdhury (2014) state that "If firms are conscious of cost of debt and subsequent financial distress, they should decrease leverage following rating downgrades, and increase leverage following rating upgrades” (p. 2). Consequently, we put forward the following hypothesis:

Hypothesis 2. Credit rating downgrades are positively associated with banks' capital ratios, while credit rating upgrades are negatively associated with banks' capital ratios.

Prior studies such as Kisgen (2006); and Samaniego-Medina and di Pietro (2019) suggest that credit rating designated as positive and negative signs may condition capital structure decisions. For example, Kisgen's (2006) CR-CS hypothesis documents that firms near a credit upgrade into a higher major rating category (e.g., from $A$ to $A A$ ), i.e., with a rating modified 
by a plus sign (e.g., $A^{+}$) are more likely to issue equity instead of debt, if the discrete future benefits of the actual upgrade ${ }^{8}$ (e.g., from $A+$ to $A A$ ) outweigh the usual costs of equity financing. Likewise, Kisgen (2006) finds that firms which have a rating with a minus sign (e.g., A-), i.e., firms close to a credit rating downgrade into a lower major category (e.g., from $A$ - to $B B B$ ), are more likely to issue equity instead of debt, to prevent the downgrade.

In this study, we re-examine the CR-CS hypothesis in the context of banks' capital by altering the focus of the CR-CS model from debt/equity net issuance to changes in banks' capital ratios. This is because banks' capital ratios are associated with banks' failures and have been found to be connected to credit ratings (Blume et al., 1998; Estrella, 2000). Thus, the above explains why some banks hold capital above the regulatory minimum consistent with the capital buffer theory (e.g., Diamond and Rajan, 2000; Jackson et al., 1999). Drawing from the CR-CS model, we contend that banks near a credit rating upgrade or downgrade may change their capital ratios through equity issues instead of debt to obtain the benefits of higher ratings and prevent the extra costs (e.g., higher costs funds and smaller pool of investors) that result from a downgrade. Thus, whereas higher ratings may bring significant benefits, averting downgrades may only prevent extra costs suggesting that the benefits of upgrades may outweigh the benefits of averted downgrades. Furthermore, assuming that credit ratings are important signals to the investors (Kisgen, 2009; Gu et al., 2018), issuing equity should be cheaper for banks with plus sign (e.g., $A^{+}$), than those with minus sign (e.g., A-), all other factors being equal. Consequently, we expect that the net benefits of the actual rating upgrade to be greater from banks’ perspective. This, in turn, may push banks’ managers to increase their capital ratios, i.e., deviate from the usual pursue of the "leverage ratchet effect" in the

\footnotetext{
${ }^{8}$ S\&P inform that 'Ratings from 'AA' to 'CCC' may be modified by the addition of a plus (+) or minus (-) sign to show relative standing within the major rating categories” (S\&P, 2019).
} 
short-run, until an actual upgrade materializes. Such expectations are in line with the capital buffer theory and lead to our third hypothesis.

Hypothesis 3: The positive association between credit ratings and bank capital ratios will be more pronounced for credit ratings designated with plus signs compared with minus signs.

Research evidence suggests that companies are keen not to lose, or to regain, their investment credit rating status, and thus actively adjust capital structure by releasing debt, issuing equity or both (Kisgen, 2019; Lemmon and Roberts, 2010). Kisgen (2009) observes that firms downgraded to a non-investment grade (so-called “fallen angels”) are twice as likely to decrease leverage. Such a phenomenon may be driven by rating-contingent regulations, various rating triggers, and investors herd behaviour brought about by a loss of the investment rating status ${ }^{9}$. These, in turn, lead to a substantial increase (decrease) in costs (sources) of funding.

Banks are more opaque than non-financial firms (e.g., Hau et al., 2013; Morgan, 2002) hence, credit ratings' signaling function should play a greater role in diminishing asymmetric information between banks and their investors. Upon becoming a "fallen angel", a bank faces an array of negative consequences, leading to a reduction in profits (Richards and Deddouche, 2003), an increase of liabilities versus assets and eventually a decline in its capacity to generate capital internally, and thus a fall in capital ratio (ECB, 2008). Furthermore, Hau et al. (2013) document that "in normal times, bank credit ratings are informative about future expected default probabilities only for the $25 \%$ lowest-rated banks with ratings of $\mathrm{BBB}+$ and below" (p. 293), i.e., mainly banks with a non-investment grade ratings. Given the above-outlined arguments we propose the following hypothesis.

\footnotetext{
9 A notable example of rating-triggers occurred in 2002 when, after a downgrade to a non-investment status, Enron faced USD3.9b in early debt repayment (Kisgen, 2019).
} 
Hypothesis 4. Credit rating downgrades from investment- to non-investment-grade are negatively associated with banks' capital ratios.

Korajczyk and Levy (2003) find evidence that highly rated non-financial firms are more likely to diverge from their optimal leverage ratios in efforts to "time the markets”. Kisgen (2009) documents an asymmetric effect of credit ratings on corporate firms' speed of adjustment to target leverage. He observes that firms adjust their capital structure faster after being downgraded, whereas rating upgrades have no association with the speed of adjustment. The study by Huang and Shen (2015) has rendered some support for Kisgen’s (2009) findings. Wojewodzki et al. (2018) focus on credit ratings levels and find that firms with poorer credit ratings converge towards their target leverage significantly faster than firms with better credit ratings. Samaniego-Medina and di Pietro (2019) find that the deviation from the speed of adjustment is the most pronounced for non-financial European firms with BBB- ratings. This is, for firms which are the nearest to a potential downgrade to the speculative grade.

Adrian and Shin (2010) argue that managers actively adjust banks’ leverage ratios, aiming at specific target ratings. De Jonghe and Öztekin (2015) document that banks' adjustments towards optimal capital structure should depend on factors determining the costs of external funding and financial distress. More specifically, they find evidence that banks converge at a greater speed to optimum capital ratios when operating during financial crises, in countries with stronger banking supervision and more developed equity markets. Taken together, extant literature suggests that credit ratings may influence capital's adjustment speed of banks. Extending the studies in the non-financial sector to the banking sector, we put forward the following hypotheses: 
Hypothesis 5a. Credit rating levels are negatively associated with the speed at which banks adjust their capital towards target ratio.

Hypothesis 5 b. Credit rating downgrades are positively associated with the speed at which banks adjust their capital towards target ratio.

\section{Data, variables, and empirical model}

\subsection{Sample and data sources}

Our sample consists of 391 commercial banks from 76 countries (4,024 bank-year observations) from 1998 to 2013. Table A1 of Appendix A presents a full list of countries, number of banks and annual observations per country. Data relating to banks' long-term issuer default ratings are obtained from the Fitch Ratings agency, and banks' financial statements are from the Bureau Van Dijk’s Bankscope database. Annual inflation rates, GDP growth and GDP per capita come from the World Bank's Development Indicators. Data on banking crises are from Laeven and Valencia (2018). The information on countries' banking regulation, supervision and market monitoring powers is gathered from the Bank Regulation and Supervision database by the World Bank (Barth et al., 2001, 2008, 2013). Information on countries' insurance deposit schemes is extracted from a database compiled by Demirgüç-Kunt et al. (2015). Exchange rates are acquired from Thompson Financial Datastream.

\subsection{Measurement of variables}

Following prior research (De Jonghe and Öztekin, 2015), we use the ratio of equity to total assets (book values) as our dependent variable CAPITAL. The rationale is threefold. First, focusing on listed banks only (i.e., market values), would greatly diminish the size of the sample and cause a bias towards the largest banks (De Jonghe and Öztekin, 2015). Second, book values are embedded in the capital regulation of Basel Accords (Berger et al., 2008). Third, CAPITAL term corresponds to the leverage ratio from Basel III. 
We select three bank-level variables previously used in studies: bank size, profitability and credit risk (e.g., De Jonghe and Öztekin, 2015; Gropp and Heider, 2010). Besides, we control for four country-level economic variables: inflation rate, a growth rate of gross domestic product, gross domestic product per capita and periods of banking systemic crisis. Moreover, we include four regulatory variables capturing countries’ capital regulation, banking supervision, private-sector's monitoring powers and explicit deposit insurance schemes. Table A2 of Appendix A lists all the variables, their definitions, and data sources.

Following Kisgen (2009), we translate all banks' credit ratings issued by Fitch from original letter-coded grades into 19 cardinal numerical values. Consequently, each and every credit rating assigned to a bank corresponds to integers from 1 to 19 , as follows: $A A A=1, A A+=2$, $A A=3, A A^{-}=4, A+=5, A=6, A-=7, B B B+=8, B B B=9, B B B-=10, B B+=11, B B=12$ $B B-=13, B+=14, B=15, B-=16, C C C+=17, C C C=18$ and $C C=19$. Table 1 displays the frequencies and percentage share of Fitch's credit rating codes, along with corresponding integers. As such, we create the RATING variable, which captures a potential effect of credit ratings levels on banks' capital as per hypothesis 1 . Another rating variable which pertains to hypothesis 1 is $J U N K$ term, a dummy variable that equals one if a bank has a speculative-grade credit rating (coded as $B B+$ and below), and zero otherwise.

\section{Table 1}

Cardinal Coding System Corresponding to Fitch Long-Term Issuer Default Ratings Scale

\begin{tabular}{|l|c|cc|}
\hline $\begin{array}{l}\text { Rating } \\
\text { Letter } \\
\text { Coding }\end{array}$ & Cardinal Value Assigned & Frequency & Percentage Share \\
\hline \multicolumn{2}{|c|}{ Investment-grade credit ratings } & 3,024 & $75.15 \%$ \\
AAA & 1 & 3 & $0.07 \%$ \\
AA+ & 2 & 47 & $1.17 \%$ \\
AA & 3 & 156 & $3.88 \%$ \\
AA- & 4 & 427 & $10.61 \%$ \\
A+ & 5 & 452 & $11.23 \%$ \\
A & 6 & 457 & $11.36 \%$
\end{tabular}




\begin{tabular}{|l|c|cc|}
\hline A- & 7 & 514 & $12.77 \%$ \\
BBB+ & 8 & 390 & $9.69 \%$ \\
BBB & 9 & 287 & $7.13 \%$ \\
BBB- & 10 & 291 & $7.23 \%$ \\
\hline \multicolumn{2}{|c|}{ Speculative-grade credit ratings } & 1,000 & $24.85 \%$ \\
BB+ & 11 & 166 & $4.13 \%$ \\
BB & 12 & 145 & $3.60 \%$ \\
BB- & 13 & 186 & $4.62 \%$ \\
B+ & 14 & 170 & $4.22 \%$ \\
B & 15 & 140 & $3.48 \%$ \\
B- & 16 & 164 & $4.08 \%$ \\
CCC+ & 17 & 13 & $0.32 \%$ \\
CCC & 18 & 14 & $0.35 \%$ \\
CC & 19 & 2 & $0.05 \%$ \\
\hline
\end{tabular}

This table summarizes a spectrum of the banks' issuer credit ratings used by Fitch. The highest possible rating assigned $(A A A)$, is reserved for the banks with the highest credit quality and the lowest rating in the sample $(C C)$ means very high levels of credit risk (Fitch, 2018).

To investigate the effects of changes in credit ratings on banks' capital, we create two dummy variables following Kisgen (2009) and Wojewodzki et al. (2018). The DOWNGRD dummy variable equals one if a bank has been downgraded (as compared with the previous year), and zero otherwise. Likewise, the UPGRD dummy variable equals one if the bank has been upgraded, and zero otherwise. Following Kisgen (2006), we build three dummy variables to test for hypothesis 3. The CRMINUS variable equals one if a bank has a minus rating in a particular year, and zero otherwise, whereas the CRPLUS variable equals one if a bank has a plus rating, and zero otherwise. A third dummy variable $P O M$ equals one if a bank has a credit rating with either a minus or a plus sign, and zero otherwise. Our last credit rating-derived dummy variable FALLEN allows us to test the effects of downgrades (from an investment-grade to a speculative-grade rating) on banks' capital ratios. FALLEN equals one if a bank suffered a downgrade from an investment rating status in a previous year to a speculative status in the current year (thus becoming a “fallen angel”).

\subsection{Econometric model specification}

Following recent studies (De Jonghe and Öztekin, 2015; de Mooij and Keen, 2016), we model banks’ capital using a partial adjustment framework, which incorporates a lagged dependent 
variable amongst explanatory variables, as in Equation (1).

$\operatorname{CAPITAL}_{i, t}=\alpha_{0}+\alpha_{1} \operatorname{CAPITAL}_{i,(t-1)}+\alpha_{2} \operatorname{RATING}_{i, t}+\sum_{k=1}^{11} \varphi_{k} X_{k, i, t}+C_{j}+Y_{t}+\mu_{i}+v_{t}+\varepsilon_{i, t}$

Where $C A P I T A L_{i, t}$ is the capital ratio for bank $i$ in year $t, \alpha_{0}$ is a constant term, and $\alpha_{1}, \alpha_{2}$ and $\varphi_{k}$ represent the coefficients of true unknown parameters to estimate. $\operatorname{CAPITAL}_{i(t-1)}$ stands for the first lag of the outcome variable (capturing the dynamic nature of banks' capital), while $\operatorname{RATING} G_{i, t}$ is the variable capturing banks' credit rating. ${ }^{10} X$ is a vector of predictor variables of the bank's capital, consisting of $k$-factors as follows: SIZE, ROAA, RISK, INFL, GDPGROW, CRISIS, GDPPERCAP, CAP_REG, SUPERV, PRIV_MON, EDIS. $C_{j}$ represents the set of 75 country-dummy variables and accounts for the time-invariant, country-specific arrangements. $Y_{t}$ stands for the set of 15 year-dummy variables and captures directly unobservable time-specific shocks affecting all banks in the sample but changing over time. $\mu_{i}$ represents the time-invariant unobserved bank fixed effects (e.g., reputation, management performance). $v_{t}$ stands for all other time-specific effects which can fluctuate over time and affect banks in one or more countries. $\varepsilon_{i, t}$ is the error term. $\alpha_{1}$ captures the speed of banks' capital adjustment towards their target. In line with hypothesis 1 we expect the $\alpha_{2}$ coefficient to be positive ${ }^{11}$.

\footnotetext{
${ }^{10}$ In addition to the RATING variable from the base model (column 1 in Table 2), there are more regression models testing hypotheses 1-4 (5a and $5 \mathrm{~b}$ ), in which we use seven other credit-rating-related explanatory variables (and their interactions with the dependent variable), as follows: JUNK, DOWNGRD, UPGRD, CRMINUS, CRPLUS, POM, and FALLEN. Due to potentially high correlations and multicollinearity amongst these variables, and the issue of "over-parametrization", in each model we include only one or two credit-rating-related variables. This procedure also alleviates the issue of too many instruments in the models (Roodman, 2009).

${ }^{11}$ In RATING variable, letter-coded credit ratings are replaced by ordinal integers from 1 for the highest rating (AAA), to 19 for the lowest rating (CC). This is, the higher (lower) credit rating, the lower (higher) numerical value. This is why a proposed negative association between rating levels and banks' capital ratios implies the $\alpha_{2}$ coefficient to be positive. The $\alpha_{2}$ coefficient would have been negative if we had used a reverse order of integers (from 1 for the lowest rating, to 19 for the highest rating).
} 
Stolz and Wedow (2011) highlight the problem of endogeneity between bank-specific explanatory variables and the dependent variable. Using the RATING variable as an example, the endogeneity arises when some directly unobservable factors (e.g., reputation, management risk aversion) influence both banks' capital and credit ratings. Thus, “unobservable heterogeneity” occurs (Wojewodzki et al., 2018). Additionally, the relationship between ratings and capital ratios is expected to suffer from "simultaneity" when RATING depends on the current or past values of the dependent variable. Capital ratio largely determines banks' overall default risk and thus has a direct effect on the ratings assigned by a rating agency. Such two-way causality is likely to be amplified by existing capital regulation.

In the presence of endogeneity, the Ordinary Least Squares (OLS) or the Fixed Effects (FE) methods tend to produce biased coefficients (De Jonghe and Öztekin, 2015). We tackle the problem of endogeneity by using a two-step system version of Blundell and Bond's (1998) generalized method of moments (GMM) estimator, often proclaimed as the most efficient for handling dynamic models of firms’ capital structure with endogeneity (Flannery and Hankins, 2013). To alleviate the problem of potentially downward-biased standard errors, we use Windmeijer's small-sample corrected standard errors. Besides, we apply two measures to control for a too-large number of instruments. First, we keep the number of instruments below the number of banks in the sample (Roodman, 2009). Second, we restrict the lags' length of instruments to four (Stolz and Wedow, 2011). In all models, lagged dependent variable, bank-specific, credit-rating-related and interaction variables are treated as endogeneous, while the remaining variables are considered exogenous (Wojewodzki et al., 2018). ${ }^{12}$

\section{Results and discussions}

\footnotetext{
${ }^{12}$ We re-run the regressions with macroeconomic and regulatory variables treated as endogeneous. The results are virtually unchanged.
} 


\subsection{Summary statistics}

Figure 1 indicates that except for the lowest category of credit ratings (below $B$ ), banks with the highest credit rating $(A A A)$ have the lowest capital ratios. As we move down the rating spectrum, banks' capitalization improves. Therefore, Figure 1 offers initial support to hypothesis 1 .

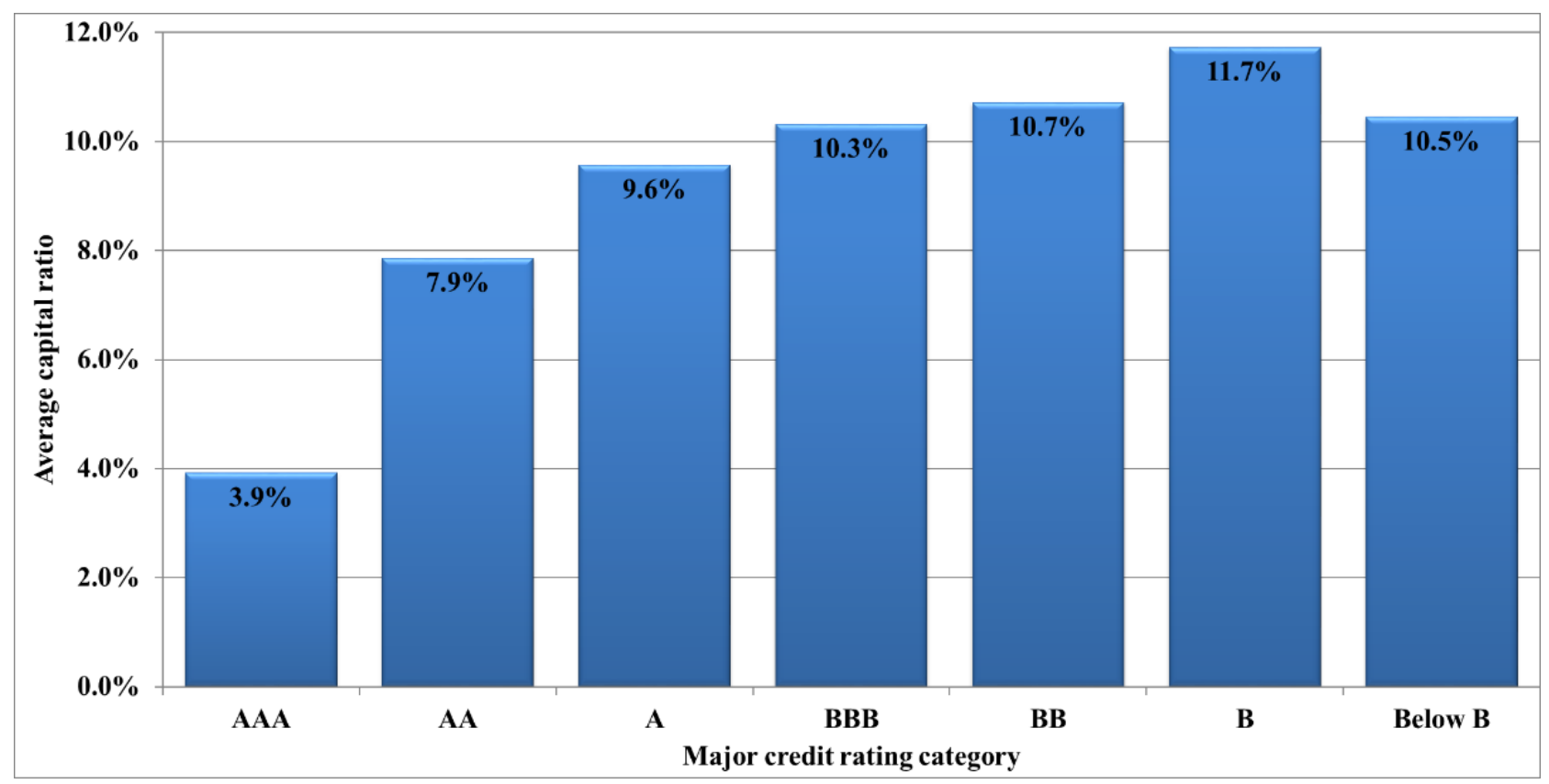

Figure. 1. Banks’ average capital ratios by major credit rating categories

Regarding Figure 2, only three out of six (five) ratings with plus (minus) signs correspond to larger average capital ratios, compared with ratings with no sign from the same major category of credit ratings (e.g., $B B+$ and $B B$ - vs. $B B$ ). Only in rating categories $A$ and $B$ do banks with both plus and minus sign credit ratings have an average capital ratio greater than banks with credit ratings without the signs. Thus, Figure 2 stands in opposition to hypothesis 3, and Kisgen (2006). 


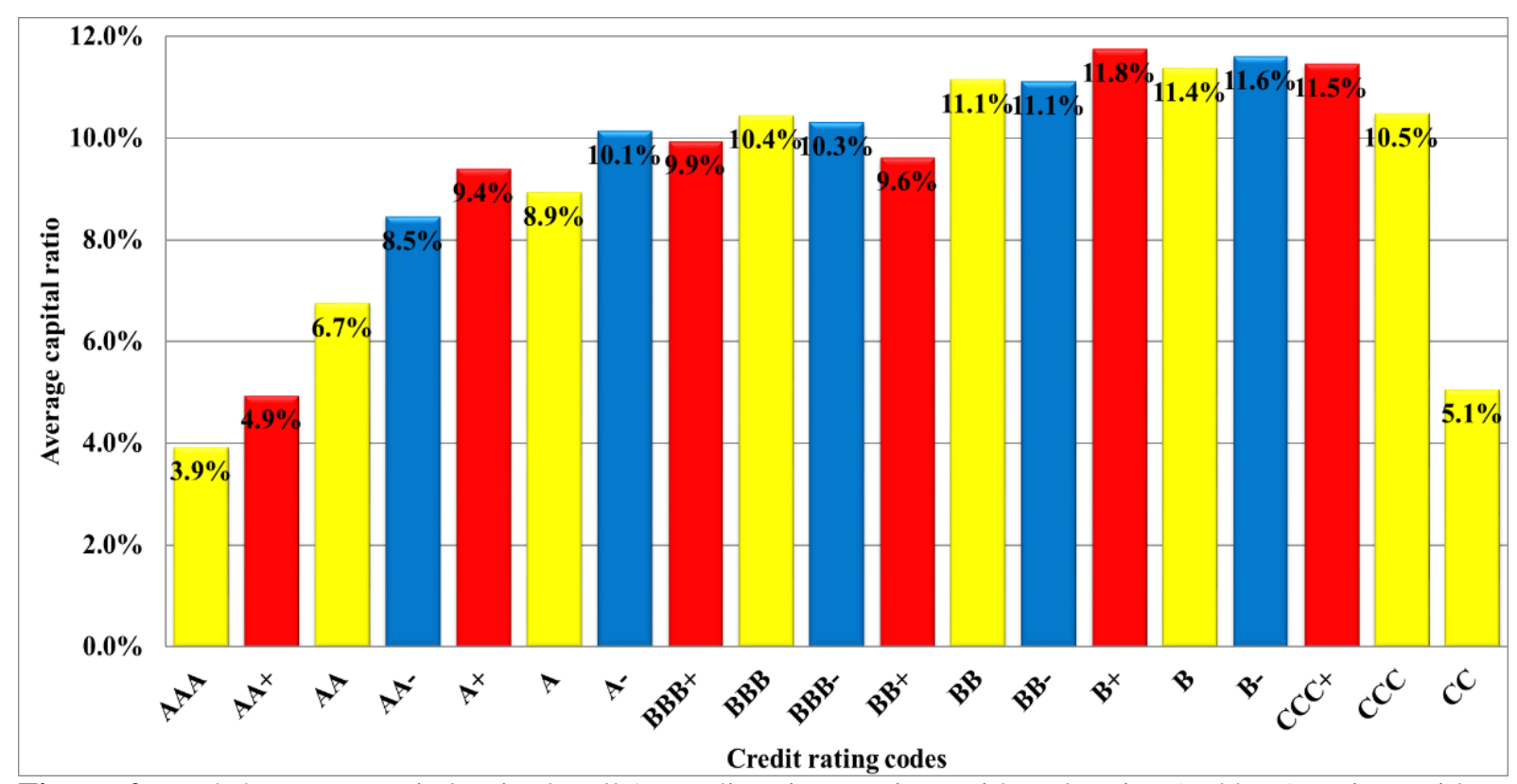

Figure. 2. Banks' average capital ratios by all 19 credit ratings: ratings with a plus sign (red bars), ratings with a minus sign (blue bars), and ratings with no signs (yellow bars).

\subsection{The determinants of banks' capital ratio}

Table 2 reports that the coefficients on CAPLAG term are above (below) those from the untabulated estimates from the FE (OLS) regressions, indicating that the two-step system GMM models are correctly specified. The m1, m2 and Hansen’s tests also suggest that the GMM models are correctly specified. Furthermore, coefficients on CAPLAG are all within the range of 0 to 1 , similar in magnitude and of high statistical significance. Summing up, the results indicate that banks adjust their capital ratios over time to reach their target, in line with recent studies (De Jonghe and Öztekin, 2015; de Mooij and Keen, 2016). For instance, the coefficient on CAPLAG from column (1) indicates that, on average, rated banks from the sample eliminate, annually, just over 28\% (1 - 0.7179) of the distance between their current and target capital ratio. At such speed, half the gap between the actual and the target capital is bridged in approximately two years. ${ }^{13}$ In their global study, De Jonghe and Öztekin (2015) report a similar speed of $29 \%$.

\footnotetext{
${ }^{13}$ Same as in De Jonghe and Öztekin (2015), we calculate the half-life of adjustment process as $\ln (0.5) / \ln (1-$
} 


\subsection{Effects of credit ratings on banks' capital ratios}

To find out if previously examined effects of credit ratings on non-financial firms hold for banks, eight credit-rating-related variables have been integrated into six GMM regression models presented in Table 2. The estimated coefficient on RATING and JUNK variables in column (1), and (2), respectively, provide support to the initial conclusion, suggesting that, unlike for non-financial firms (e.g., Wojewodzki et al., 2018), we find no statistical evidence of an association between credit rating levels and banks' capital structure. Column 3 of Table 2 tests the expected positive (negative) relationship between credit rating downgrades (upgrades) and banks’ capital ratios. Coefficients are statistically insignificant, adding to a general picture of a relative immunity of banks' capital ratio to credit ratings. Our results could be an outcome of banks' creditors being generally passive in monitoring and disciplining banks (Admati and Hellwig, 2019), due to government guarantees, the perception of markets that banks are "too big to fail" and/or low informational value of banks' credit ratings (e.g., Abreu and Gulamhussen, 2013; Belkhir, 2013; Hau et al., 2013).

Regression results presented in columns (4) and (5) test hypothesis 3, which posits a positive relationship between credit ratings with plus or minus signs (near rating upgrade or downgrade, respectively) and banks' capital ratios with the effect of "plus sign" being pronounced relative to "minus sign". The results provide some support for hypothesis 3. Specifically, while coefficients on CRPLUS and POM are statistically significant at the 5\% level, the coefficient on CRMINUS appears positive but insignificant. ${ }^{14}$ Thus, it appears that banks with plus-sign credit ratings (e.g., $A A^{+}$), on average, have higher capital to total assets ratios, holding all other factors constant.

speed of adjustment). 1 - speed of adjustment equals CAPLAG's coefficient i.e., the length of half-life equals ln (0.5)/ln (1-0.2821) or 2.09 years.

${ }^{14}$ Lack of statistical significance for the CRMINUS coefficient is in stark contrast with Kisgen (2006). 
Table 2

Two-step system GMM: credit rating effects

\begin{tabular}{|c|c|c|c|c|c|c|c|}
\hline $\begin{array}{l}\text { Independent } \\
\text { Variable }\end{array}$ & $\begin{array}{l}\text { Expected } \\
\text { Sign } \\
\end{array}$ & $\begin{array}{l}\text { (1) } \\
\text { Hypothesis } 1\end{array}$ & $\begin{array}{l}\text { (2) } \\
\text { Hypothesis } 1\end{array}$ & $\begin{array}{l}\text { (3) } \\
\text { Hypothesis } 2\end{array}$ & $\begin{array}{l}\text { (4) } \\
\text { Hypothesis } 3\end{array}$ & $\begin{array}{l}\text { (5) } \\
\text { Hypothesis } 3\end{array}$ & $\begin{array}{l}6) \\
\text { Hypothesis } 4\end{array}$ \\
\hline CAPLAG & + & $\begin{array}{l}0.7179 * * \\
(17.64)\end{array}$ & $\begin{array}{l}0.7096 * * \\
(15.38)\end{array}$ & $\begin{array}{l}0.7309 * * \\
(20.03)\end{array}$ & $\begin{array}{l}0.7090^{* *} \\
(16.27)\end{array}$ & $\begin{array}{l}0.7175^{* *} \\
(17.57)\end{array}$ & $\begin{array}{l}0.7102 * * \\
(15.99)\end{array}$ \\
\hline RATING & + & $\begin{array}{l}-0.0124 \\
(-0.36)\end{array}$ & & & & & \\
\hline JUNK & + & & $\begin{array}{l}-0.0745 \\
(-0.41)\end{array}$ & & & & \\
\hline DOWNGRD & + & & & $\begin{array}{l}-0.0833 \\
(-0.57)\end{array}$ & & & \\
\hline UPGRD & - & & & $\begin{array}{l}0.1196 \\
(0.53)\end{array}$ & & & \\
\hline CRMINUS & + & & & & $\begin{array}{l}0.0706 \\
(0.56)\end{array}$ & & \\
\hline CRPLUS & + & & & & $\begin{array}{l}0.2747^{*} \\
(2.17)\end{array}$ & & \\
\hline$P O M$ & + & & & & & $\begin{array}{l}0.2016^{*} \\
(2.00)\end{array}$ & \\
\hline FALLEN & - & & & & & & $\begin{array}{l}-0.9269 * \\
(-1.97)\end{array}$ \\
\hline Banks & & 391 & 391 & 391 & 391 & 391 & 391 \\
\hline Observations & & 3,631 & 3,631 & 3,631 & 3,631 & 3,631 & 3,631 \\
\hline Period of Est. & & 1998-2013 & $1998-2013$ & $1998-2013$ & 1998-2013 & 1998-2013 & $1998-2013$ \\
\hline m1 (Z-statistic) & & $-5.83 * *$ & $-5.74 * *$ & $-5.85 * *$ & $-5.78 * *$ & $-5.78^{* *}$ & $-5.79 * *$ \\
\hline m2 (Z-statistic) & & 1.02 & 1.03 & 1.00 & 1.01 & 1.05 & 1.10 \\
\hline Hansen Test & & 0.34 & 0.32 & 0.59 & 0.27 & 0.40 & 0.51 \\
\hline
\end{tabular}

The dependent variable is the book value of equity to total assets ratio (CAPITAL). $\mathrm{m} 1$ and $\mathrm{m} 2$ are tests for first order and second order serial correlation in the first-differenced residuals, under the null of no serial correlation. The Hansen test is a test of the overidentifying restrictions, distributed as chi-square under the null of instrument validity. T-statistics based on asymptotic standard errors that are robust for heteroskedasticity and clustered by the banks are in the parentheses. *, and ** indicate coefficients' significance at $5 \%$, and $1 \%$ level, respectively. In the models, we include the year and country dummies, the bank-, and country-level determinants of capital (described in Table A2 in Appendix A) other than those directly involved in hypotheses. For the sake of brevity, they are not presented. Untabulated estimates from OLS and FE models are used to check the robustness of GMM results.

In line with the CR-CS hypothesis (Kisgen, 2006), the results may be explained by the fact that managers of banks close to a credit rating upgrade routinely pursue higher capital ratios (through an issuance of equity) to qualify for an upgrade into a higher major rating category (e.g., from $A$ to $A A$ ). This, in turn, indicates that future benefits of the actual rating upgrade, such as even cheaper debt, are substantial and can make banks deviate from the usual “leverage ratchet effect”, at least until an actual upgrade materializes. Such a positive "plus sign" effect also conforms with the capital buffer theory postulating that banks often aim at capital ratios above the regulatory minimum, to benefit from capital-related trade-offs. ${ }^{15}$

\footnotetext{
${ }^{15}$ For example, Jackson et al. (1999) argue that following the Basel I Accord, banks hoard additional capital (buffers), in order to meet credit rating agencies’ requirements.
} 
Regarding the results reported in column 4, we would expect a bank with e.g., an $A A+$ credit rating to hold 0.27 percentage point more capital than a bank with an $A A$ credit rating, ceteris paribus. This corresponds to the short-run "plus sign" effect on banks' capital ratio. With the coefficient on CAPLAG in column (4) equal to 0.7090, we calculate the long-run "plus sign" effect as follows: $\beta C R P L U S /(1-\beta C A P L A G)$ (see de Mooij and Keen, 2016). This yields the long-run effect of 0.94 percentage point. Our findings suggest the presence of an important channel through which a credit rating agency can, in the long run, bring an increase of about 1 percentage point in banks' capital. To put such a "plus sign” effect in the right perspective, the required minimum leverage ratio ${ }^{16}$ from the Basel III Capital Accord is 3\%. The estimated coefficient on $P O M$ in column (5) merges the effects of both rating-related variables from column (4) and carries a lower statistical and economic level of significance, as expected.

Column 6 focuses on the importance of a rating downgrade from an investment- to a non-investment-grade (e.g., Kisgen, 2009; Lemmon and Roberts, 2010). The estimated coefficient on the FALLEN term offers support to hypothesis 4. A negative sign is in line with the strand of literature arguing that upon becoming "fallen angels", banks face greater costs of borrowed funds from a diminished pool of investors. This, in turn, leads to a fall in banks' profitability (Richards and Deddouche, 2003), bringing a decline in their potential to generate capital internally, thus a decline in banks’ capital (ECB, 2008). The short-run “fallen angel” effect is approximately 0.9 percentage point, while the long-run effect amounts to a staggering 3.2 percentage points and as such highlights the inadequacy of the $3 \%$ minimum regulatory leverage ratio in Basel III.

\footnotetext{
${ }^{16}$ Basel III's leverage ratio is the ratio of Tier 1 capital to the average total consolidated assets of a given bank i.e., equivalent to our CAPITAL term.
} 
Table 3 presents the estimated results of four GMM models including interactions between the first lag of the dependent variable (CAPLAG), and five rating-related variables. The first two interaction variables $R A T I N G * C A P L A G$ and $J U N K^{*} C A P L A G$ test hypothesis 5 a (columns (1), and (2)). The third and fourth interactions DOWNGRD*CAPLAG and FALLEN*CAPLAG in column (3) and (4), address hypothesis 5b.

Table 3

Two-step system GMM: tests of hypotheses 5 and 6 using interaction terms

\begin{tabular}{|c|c|c|c|c|c|}
\hline & & (1) & $(2)$ & (3) & (4) \\
\hline Independent Variable & $\begin{array}{l}\text { Expected } \\
\text { Sign }\end{array}$ & $\begin{array}{l}\text { Hypothesis } \\
5 a\end{array}$ & $\begin{array}{l}\text { Hypothesis } \\
5 a\end{array}$ & $\begin{array}{l}\text { Hypothesis } \\
\text { 5b }\end{array}$ & $\begin{array}{l}\text { Hypothesis } \\
\text { 5b }\end{array}$ \\
\hline CAPLAG & + & $0.8544^{* *}$ & $0.7525^{* *}$ & $0.7274^{* *}$ & $0.7137 * *$ \\
\hline RATING & + & $\begin{array}{l}(11.76) \\
0.1330 * \\
(2.14)\end{array}$ & $(16.64)$ & (18.11) & (15.98) \\
\hline RATING*CAPLAG & - & $\begin{array}{l}-0.0149 * \\
(-2.52)\end{array}$ & & & \\
\hline JUNK & + & & $\begin{array}{l}1.1267^{*} \\
(1.99)\end{array}$ & & \\
\hline$J U N K^{*} C A P L A G$ & - & & $\begin{array}{l}-0.1168 * \\
(-2.29)\end{array}$ & & \\
\hline DOWNGRD & + & & & $\begin{array}{l}0.1387 \\
(0.52)\end{array}$ & \\
\hline$D O W N G R D^{*} C A P L A G$ & - & & & $\begin{array}{l}-0.0182 \\
(-0.53)\end{array}$ & \\
\hline FALLEN & - & & & & $\begin{array}{l}0.8024 \\
(0.60)\end{array}$ \\
\hline FALLEN*CAPLAG & - & & & & $\begin{array}{l}-0.1875 \\
(-1.45)\end{array}$ \\
\hline Banks & & 391 & 391 & 391 & 391 \\
\hline Observations & & 3,631 & 3,631 & 3,631 & 3,631 \\
\hline $\begin{array}{l}\text { Period of Est. } \\
\text { m1 (Z-statistic) }\end{array}$ & & $\begin{array}{l}1998-2013 \\
-5.94^{* *}\end{array}$ & $\begin{array}{l}1998-2013 \\
-5.93 * *\end{array}$ & $\begin{array}{l}1998-2013 \\
-5.92 * *\end{array}$ & $\begin{array}{l}1998-2013 \\
-5.78^{* *}\end{array}$ \\
\hline $\begin{array}{l}\text { m2 (Z-statistic) } \\
\text { Hansen Test (p-value) }\end{array}$ & & $\begin{array}{l}1.00 \\
0.13\end{array}$ & $\begin{array}{l}0.98 \\
0.19\end{array}$ & $\begin{array}{l}1.02 \\
0.32\end{array}$ & $\begin{array}{l}1.13 \\
0.48\end{array}$ \\
\hline
\end{tabular}

The dependent variable is the book value of equity to total assets ratio (CAPITAL). $\mathrm{m} 1$ and $\mathrm{m} 2$ are tests for first order and second order serial correlation in the first-differenced residuals, under the null of no serial correlation. The Hansen test is a test of the overidentifying restrictions, distributed as chi-square under the null of instrument validity. T-statistics based on asymptotic standard errors that are robust for heteroskedasticity and clustered by the banks are in the parentheses. *, and ** indicate coefficients' significance at $5 \%$, and $1 \%$ level, respectively. In the models, we include the year and country dummies, the bank-, and country-level determinants of capital (see Table A2 in Appendix A) other than those directly involved in hypotheses. For the sake of brevity, they are not presented.

Hypothesis 5a posits that credit rating levels are negatively associated with banks' speed of adjustment towards target capital ratios. In other words, the higher (lower) the rating level, the slower (faster) the speed of adjustment, in line with the studies by Korajczyk and Levy (2003) and Wojewodzki et al. (2018). The coefficients on RATING*CAPLAG and JUNK*CAPLAG 
are negative, statistically significant at the 5\% level and support hypothesis 5a. The coefficient on RATING*CAPLAG (-0.0149) indicates that, on average, a bank with an $A$ credit rating annually reduces 0.01 percentage point more of the gap between its actual and target capital ratio, as compared to a bank with an $A+$ credit rating, ceteris paribus. Likewise, the disparity in the capital adjustment between banks with the highest and the lowest credit rating within the investment-grade status (between $A A A$ and $B B B$-) amounts to approximately one-seventh of a percentage point. Thus, although highly statistically significant, the effect of credit rating levels on banks' speed of adjustment is minimal in economic terms compared with corporate entities as reported by Wojewodzki et al. (2018), which was over 70 times larger. In a similar vein, interpreting the coefficient on $J U N K^{*} C A P L A G$, on average, a bank with a speculative-grade credit rating closes 0.12 percentage point more of the gap between its current and the target capital than a bank with investment-grade status, ceteris paribus.

Taken together, both interactions indicate that credit ratings have relatively little economic impact on the speed of banks' capital adjustments. We offer two potential explanations for such findings. First, banks with lower credit ratings, especially those with a speculative status, might lack the necessary flexibility to adjust capital due to a weak financial position and poor access to capital markets (Berger et al., 2008). Thus, while being keen to adjust their capital at a faster rate (as argued by Kisgen (2006) and Wojewodzki et al. (2018)), their predicament makes the actual increase in adjustment speed minimal, and the adjustment process painfully long. Furthermore, evidence suggests that unlike most non-financial firms, even banks with very low capital ratios avoid deleveraging. Instead, banks pursue dividend payouts, stock buybacks, and borrow even more whenever possible (the so-called "leverage ratchet effect", as in Admati et al. (2018)). Second, credit ratings are amongst bank-level determinants of capital structure. Thus, their minimal economic effect aligns with Gropp and Heider (2010), 
who document that the speed of capital adjustment is almost solely determined by bank fixed effects, while bank-level variables (e.g., size, profitability) only "very slightly" affect the adjustment speed.

Columns 3 and 4 from Table 3 indicate statistically insignificant coefficients on DOWNGRD*CAPLAG, and FALLEN*CAPLAG. Hypotheses 5b appear unsupported and thus our results are inconsistent with the findings of Huang and Shen (2015), and Kisgen (2009) in the context of corporate firms. This may suggest that banks, unlike non-financial firms, generally do not have a minimum credit rating target, or attach a lower weight to this issue.

\section{Robustness tests}

\subsection{Robustness of rating effects for "too-big-to-fail” banks}

The financial crisis of 2007-2009 supports the argument that systemically important, "too-big-to-fail" banks pose a great threat to the international financial system and economies (Admati and Hellwig, 2019). In the aftermath of the financial crisis, research evidence shows that systemically important banks enjoy subsidies, lower funding costs and insulation from negative news, and can pursue costless risk-taking behaviour (Abreu and Gulamhussen, 2013). In other words, "too-big-to-fail" banks consciously capitalize on immunity from market discipline (Belkhir, 2013). Some authors argue that systematic rating bias in favour of the largest banks is responsible for the diminished information value of credit ratings (Hau et al., 2013).

To examine if rating effects from Table 2 apply to the "too-big-to-fail" set of banks, we create two dummy variables: TBTF_5 (TBTF_25) equals one if a bank's total assets constitute 50\% (25\%) or more of the country's annual GDP, and zero otherwise. Thus, we select the most 
systemically important banks relative to the size of the country’s economy, as in Houston et al. (2010). Table 4 exhibits results for regression models from Table 2 re-estimated with TBTF_5 (the upper panel) and TBTF_25 (the bottom panel), and their interactions with rating-related variables. ${ }^{17}$ Models from columns (1) to (3) coincide with credit rating effects found to be statistically significant in Table 2 . In both panels, the coefficients on CRPLUS*TBTF_5 and CRPLUS*TBTF_25 carry opposite signs and are larger than the coefficient on CRPLUS. This indicates that while the majority of sampled banks act in line with the capital buffer theory and $C R$-CS hypothesis, the most systemically important banks use a plus-sign-enhanced credit rating as an opportunity to further reduce their capital ratios, which supports the moral hazard theory ${ }^{18}$.

Table 4

Robustness of results for "too-big-to-fail” banks

\begin{tabular}{|c|c|c|c|c|}
\hline Independent Variable & $\begin{array}{l}\text { Expected } \\
\text { Sign }\end{array}$ & (1) & (2) & (3) \\
\hline CAPLAG & + & $\begin{array}{l}0.7097 * * \\
(16.25)\end{array}$ & $\begin{array}{l}0.7215^{* *} \\
(17.05)\end{array}$ & $\begin{array}{l}0.7168^{* *} \\
(15.62)\end{array}$ \\
\hline CRPLUS & + & $\begin{array}{l}0.2900 * \\
(2.05)\end{array}$ & & \\
\hline CRPLUS*TBTF50 & - & $\begin{array}{l}-0.8300 * * \\
(-2.86)\end{array}$ & & \\
\hline$P O M$ & + & & $\begin{array}{l}0.2847 * \\
(2.55)\end{array}$ & \\
\hline POM*TBTF50 & - & & $\begin{array}{l}-0.5564^{*} \\
(-1.96)\end{array}$ & \\
\hline FALLEN & - & & & $\begin{array}{l}-0.8704 \\
(-1.76)\end{array}$ \\
\hline FALLEN*TBTF50 & + & & & $\begin{array}{l}0.8486 \\
(0.64)\end{array}$ \\
\hline Banks & & 391 & 391 & 391 \\
\hline Observations & & 3,631 & 3,631 & 3,631 \\
\hline Period of Est. & & $1998-2013$ & $1998-2013$ & $1998-2013$ \\
\hline m1 (Z-statistic) & & $-5.77 * *$ & $-5.80 * *$ & $-5.80 * *$ \\
\hline m2 (Z-statistic) & & 0.99 & 1.02 & 1.11 \\
\hline Hansen Test (p-value) & & 0.35 & 0.40 & 0.12 \\
\hline Independent Variable & $\begin{array}{l}\text { Expected } \\
\text { Sign }\end{array}$ & (1) & (2) & (3) \\
\hline CAPLAG & + & $\begin{array}{l}0.7080^{* *} \\
(16.15)\end{array}$ & $\begin{array}{l}0.7245^{* *} \\
(18.32)\end{array}$ & $\begin{array}{l}0.7083^{* *} \\
(15.79)\end{array}$ \\
\hline CRPLUS & + & $\begin{array}{l}0.3665^{*} \\
(2.46)\end{array}$ & & \\
\hline CRPLUS*TBTF25 & - & $\begin{array}{l}-0.7172 * \\
(-2.22)\end{array}$ & & \\
\hline POM & + & & $\begin{array}{l}0.3069 * * \\
(2.66)\end{array}$ & \\
\hline POM*TBTF25 & - & & $-0.4254 *$ & \\
\hline
\end{tabular}

\footnotetext{
${ }^{17}$ For the sake of brevity, we present only the models where coefficients on credit rating-related variables and/or interaction terms are statistically significant at the $1 \%$ or $5 \%$ level.

${ }^{18}$ Moral hazard theory states that in the absence of minimum capital regulatory requirements, banks choose to hold dangerously lower capital levels than otherwise required (Mishkin, 2000).
} 


\begin{tabular}{llll} 
FALLEN & - & $(-2.10)$ & -0.9973 \\
& & & $(-1.84)$ \\
FALLEN*TBTF25 & + & & 0.2869 \\
& & & $(0.26)$ \\
\hline Banks & & 391 & 391 \\
Observations & 391 & 3,631 & 3,631 \\
Period of Est. & 3,631 & $1998-2013$ & $1998-2013$ \\
m1 (Z-statistic) & $1998-2013$ & $-5.86^{* *}$ & $-5.77^{* *}$ \\
m2 (Z-statistic) & $-5.75^{* *}$ & 1.02 & 1.09 \\
Hansen Test (p-value) & 0.97 & 0.59 & 0.55 \\
\hline
\end{tabular}

The dependent variable is the book value of equity to total assets ratio (CAPITAL). $\mathrm{m} 1$ and $\mathrm{m} 2$ are tests for first order and second order serial correlation in the first-differenced residuals, under the null of no serial correlation. The Hansen test is a test of the overidentifying restrictions, distributed as chi-square under the null of instrument validity. T-statistics based on asymptotic standard errors that are robust for heteroskedasticity and clustered by the banks are in the parentheses. *, and ** indicate coefficients' significance at $5 \%$, and $1 \%$ level, respectively. In the models, we include the year and country dummies, remaining rating-related variables, their interactions with TBTF_5 and TBTF_25 dummy, the bank- and country-level determinants of capital (described in Table A2 in Appendix A). For the sake of brevity, they are not presented.

This suggests that for the most systemically important banks, future benefits of a rating upgrade are not large enough to increase capital ratios. This is against the backdrop that the largest banks in our sample, on average, have the lowest capital ratios while enjoying the highest credit ratings (see Figure 3). More specifically, we can observe that banks from the first (tenth) decile, i.e., the smallest (the largest) banks by total assets, on average, have the lowest (the highest) credit ratings: $B B$ - and $A A$-, respectively. Such evidence may indicate special, favourable treatment for banks widely considered to be "too big to fail" (e.g., Hau et al., 2013; Ueda and di Mauro, 2013). Additionally, our findings correspond with the "leverage ratchet effect”, being more pronounced for large, internationally active banks (see Admati and Hellwig, 2019). Lastly, the estimated output from column 3 suggests that the "fallen angel" effect is the only association between credit ratings and capital ratios which applies to all sampled banks, irrespective of their systemic importance. This is not surprising, given the negative implications (e.g., regulatory) stemming from downgrades to speculative-grade status, as argued by e.g., Deb et al. (2011), and Kisgen (2019). 


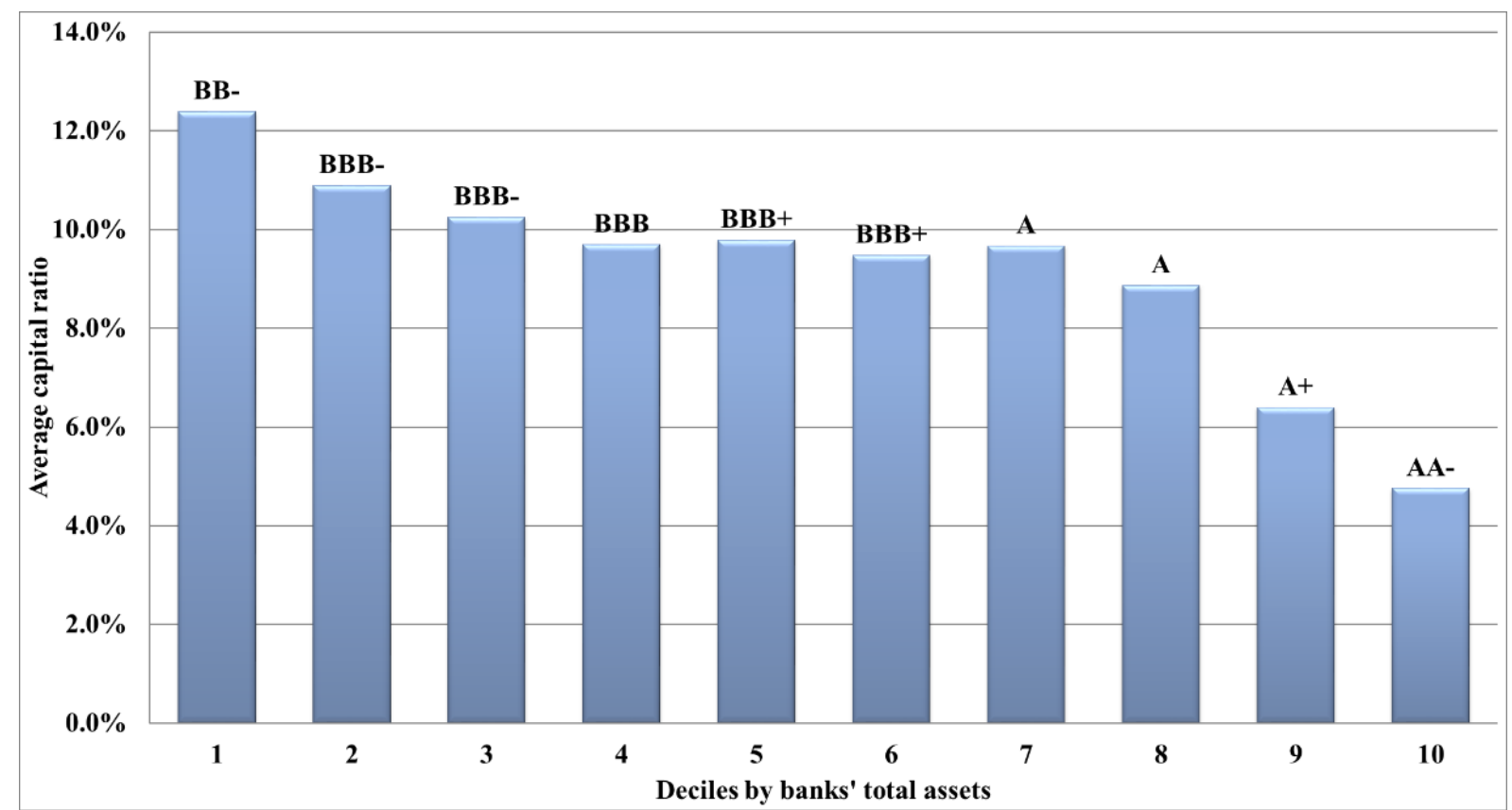

Figure. 3. Banks' average capital ratios median values (with corresponding median credit ratings) by banks' total assets deciles.

\subsection{Robustness tests: countries’ financial architecture}

We check if the documented influence of countries' financial orientation on associations between credit ratings and capital structure of corporate firms (Huang and Shen, 2015; Wojewodzki et al., 2018) holds for banks. To capture the degree to which a country’s financial markets are market-based, we follow Tadesse (2006) and use the country-specific, time-variant FINARCH variable. $^{19}$ We split the sample along FINARCH median values such that 38 countries are assigned to each group: FINARCH(Low) and FINARCH(High). The results from Table 5A suggest that credit ratings appear to be more significant in the market-based countries, thereby rendering some support for Wojewodzki et al.'s (2018) findings. For instance, coefficients on CRPLUS, POM and FALLEN, in Table 5A, are in line with those in Table 2 but more statistically significant and larger. On the other hand, Table 5B has no statistically significant rating-related factors. ${ }^{20}$ In sum, banks seem to be even more immune to credit ratings in countries that are more bank-based.

\footnotetext{
19 For a detailed definition of FINARCH variable please see Table A2 in Appendix A.

20 Pairwise statistical tests of difference between the coefficients on credit rating-related variables for two sub-samples confirm that the coefficients are statistically different at the $5 \%$ and $1 \%$ level.
} 
Table 5A

Robustness of results and countries' financial architecture: FINARCH (high) sample

\begin{tabular}{|c|c|c|c|c|c|c|c|}
\hline $\begin{array}{l}\text { Independent } \\
\text { Variable }\end{array}$ & $\begin{array}{l}\text { Expected } \\
\text { Sign }\end{array}$ & (1) & (2) & (3) & (4) & (5) & (6) \\
\hline CAPLAG & + & $\begin{array}{l}0.7180 * * \\
(14.79)\end{array}$ & $\begin{array}{l}0.7177^{* *} \\
(14.19)\end{array}$ & $\begin{array}{l}0.7389 * * \\
(16.62)\end{array}$ & $\begin{array}{l}0.7306^{* *} \\
(15.62)\end{array}$ & $\begin{array}{l}0.7526 * * \\
(17.73)\end{array}$ & $\begin{array}{l}0.7316^{* *} \\
(15.37)\end{array}$ \\
\hline RATING & + & $\begin{array}{l}-0.0998 \\
(-1.85)\end{array}$ & & & & & \\
\hline JUNK & + & & $\begin{array}{l}-0.4473 \\
(-1.66)\end{array}$ & & & & \\
\hline DOWNGRD & + & & & $\begin{array}{l}0.0064 \\
(0.04)\end{array}$ & & & \\
\hline UPGRD & - & & & $\begin{array}{l}0.1926 \\
(1.13)\end{array}$ & & & \\
\hline CRMINUS & + & & & & $\begin{array}{l}0.0300 \\
(0.19)\end{array}$ & & \\
\hline CRPLUS & + & & & & $\begin{array}{l}0.3524 * \\
(2.34)\end{array}$ & & \\
\hline$P O M$ & + & & & & & $\begin{array}{l}0.2340 \\
(1.81)\end{array}$ & \\
\hline FALLEN & - & & & & & & $\begin{array}{l}-1.1075^{*} \\
(-2.47) \\
\end{array}$ \\
\hline Banks & & 260 & 260 & 260 & 260 & 260 & 260 \\
\hline Observations & & 2,421 & 2,421 & 2,421 & 2,421 & 2,421 & 2,421 \\
\hline Period of Est. & & $1998-2013$ & $1998-2013$ & $1998-2013$ & $1998-2013$ & $1998-2013$ & $1998-2013$ \\
\hline m1 (Z-statistic) & & $-4.77 * *$ & $-4.75^{* *}$ & $-4.80 * *$ & $-4.79 * *$ & $-4.87 * *$ & $-4.84 * *$ \\
\hline $\begin{array}{l}\text { m2 (Z-statistic) } \\
\text { Hansen Test }\end{array}$ & & 1.06 & 1.03 & 1.06 & 1.01 & 1.05 & 1.00 \\
\hline (p-value) & & 0.36 & 0.31 & 0.51 & 0.22 & 0.65 & 0.37 \\
\hline
\end{tabular}

Table 5B

Robustness of results and countries' financial architecture: FINARCH (low) sample

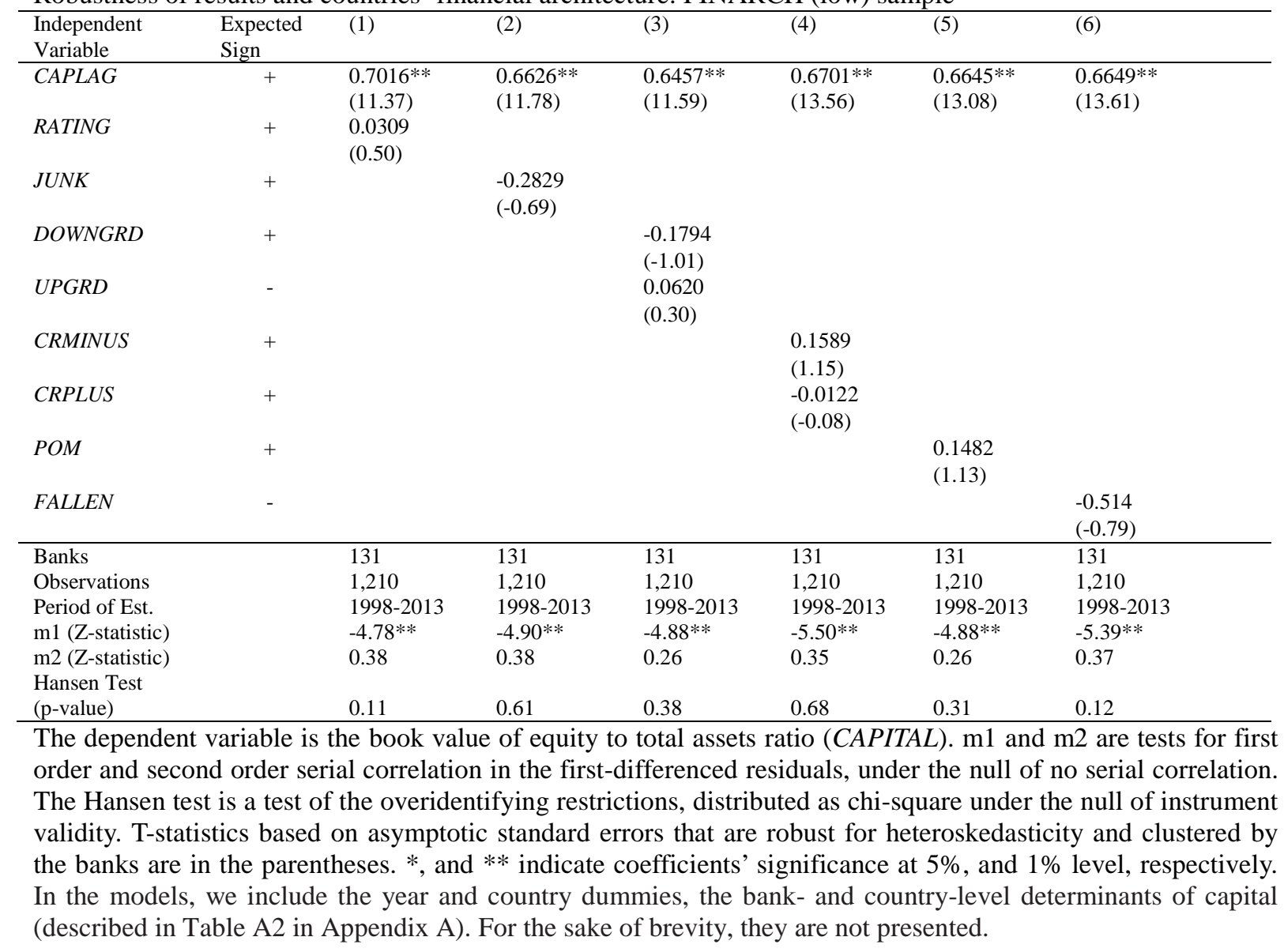




\subsection{Robustness tests: findings over time}

Another set of regression analysis is conducted after splitting the pooled sample into two periods: 1998-2006 (Table 6A) and 2007-2013 (Table 6B). Both “plus sign” and “fallen angel" effects are statistically significant for the more recent sample in Table $6 \mathrm{~B} .^{21}$ Moreover, during the initial nine years of the analyzed period (Table 6A), banks' capital ratios are unaffected by any of the rating-related terms. There are two potential reasons for our results. First, 2007 was, for many countries, the year of implementation of the Basel II Framework with its application of credit ratings. Second, as argued by many, the quality of rating processes improved over time, especially during and after the 2007-2009 financial crisis (e.g., Baghai et al., 2014; Opp et al., 2013) thus, the informational and signalling value of credit ratings increased.

Table 6A

Robustness check: Findings over time: 1998-2006 sample

\begin{tabular}{|c|c|c|c|c|c|c|c|}
\hline $\begin{array}{l}\text { Independent } \\
\text { Variable }\end{array}$ & $\begin{array}{l}\text { Expected } \\
\text { Sign }\end{array}$ & (1) & (2) & (3) & (4) & (5) & (6) \\
\hline CAPLAG & + & $\begin{array}{l}0.7985^{* *} \\
(7.49)\end{array}$ & $\begin{array}{l}0.7797^{* *} \\
(7.59)\end{array}$ & $\begin{array}{l}0.7892^{* *} \\
(9.69)\end{array}$ & $\begin{array}{l}0.7985^{* *} \\
(9.52)\end{array}$ & $\begin{array}{l}0.7884^{* *} \\
(8.45)\end{array}$ & $\begin{array}{l}0.7246^{* *} \\
(6.20)\end{array}$ \\
\hline RATING & + & $\begin{array}{l}-0.1394 \\
(-1.12)\end{array}$ & & & & & \\
\hline JUNK & + & & $\begin{array}{l}-0.0190 \\
(-0.02)\end{array}$ & & & & \\
\hline DOWNGRD & + & & & $\begin{array}{l}0.1483 \\
(0.55)\end{array}$ & & & \\
\hline UPGRD & - & & & $\begin{array}{l}0.1004 \\
(0.46)\end{array}$ & & & \\
\hline CRMINUS & + & & & & $\begin{array}{l}0.2051 \\
(0.64)\end{array}$ & & \\
\hline CRPLUS & + & & & & $\begin{array}{l}0.0884 \\
(0.27)\end{array}$ & & \\
\hline$P O M$ & + & & & & & $\begin{array}{l}0.0645 \\
(0.22)\end{array}$ & \\
\hline FALLEN & - & & & & & & $\begin{array}{l}-0.6353 \\
(-0.58)\end{array}$ \\
\hline Banks & & 211 & 211 & 211 & 211 & 211 & 211 \\
\hline Observations & & 980 & 980 & 980 & 980 & 980 & 980 \\
\hline Period of Est. & & 1998-2006 & 1998-2006 & 1998-2006 & 1998-2006 & 1998-2006 & 1998-2006 \\
\hline m1 (Z-statistic) & & $-3.40 * *$ & $-2.98 * *$ & $-3.02 * *$ & $-3.06 * *$ & $-3.02 * *$ & $-2.83^{* *}$ \\
\hline m2 (Z-statistic) & & 1.27 & 1.12 & 1.14 & 1.10 & 1.11 & 1.01 \\
\hline $\begin{array}{l}\text { Hansen Test } \\
\text { (p-value) }\end{array}$ & & 0.65 & 0.68 & 0.70 & 0.77 & 0.74 & 0.69 \\
\hline
\end{tabular}

\section{Table 6B}

${ }^{21}$ Pairwise statistical tests of difference between the coefficients on credit rating-related variables for two sub-samples confirm that the coefficients are statistically different at the $5 \%$ and $1 \%$ level. 
Robustness Check: Findings over time: 2007-2013 sample

\begin{tabular}{|c|c|c|c|c|c|c|c|}
\hline $\begin{array}{l}\text { Independent } \\
\text { Variable }\end{array}$ & $\begin{array}{l}\text { Expected } \\
\text { Sign }\end{array}$ & (1) & (2) & (3) & (4) & (5) & (6) \\
\hline CAPLAG & + & $\begin{array}{l}0.5628^{* *} \\
(12.63)\end{array}$ & $\begin{array}{l}0.5410^{* *} \\
(11.88)\end{array}$ & $\begin{array}{l}0.5910^{* *} \\
(12.61)\end{array}$ & $\begin{array}{l}0.5884 * * \\
(14.01)\end{array}$ & $\begin{array}{l}0.5472 * * \\
(11.77)\end{array}$ & $\begin{array}{l}0.5485^{* *} \\
(12.05)\end{array}$ \\
\hline RATING & + & $\begin{array}{l}-0.0425 \\
(-0.77)\end{array}$ & & & & & \\
\hline JUNK & + & & $\begin{array}{l}-0.1527 \\
(-0.50)\end{array}$ & & & & \\
\hline DOWNGRD & + & & & $\begin{array}{l}-0.0369 \\
(-0.32)\end{array}$ & & & \\
\hline UPGRD & - & & & $\begin{array}{l}0.1587 \\
(0.94)\end{array}$ & & & \\
\hline CRMINUS & + & & & & $\begin{array}{l}0.1683 \\
(1.13)\end{array}$ & & \\
\hline CRPLUS & + & & & & $\begin{array}{l}0.2881 * \\
(1.97)\end{array}$ & & \\
\hline$P O M$ & + & & & & & $\begin{array}{l}0.1950 \\
(1.32)\end{array}$ & \\
\hline FALLEN & - & & & & & & $\begin{array}{l}-1.2734^{* *} \\
(-2.71)\end{array}$ \\
\hline Banks & & 388 & 388 & 388 & 388 & 388 & 388 \\
\hline Observations & & 2,574 & 2,574 & 2,574 & 2,574 & 2,574 & 2,574 \\
\hline Period of Est. & & $2007-2013$ & $2007-2013$ & $2007-2013$ & $2007-2013$ & $2007-2013$ & 2007-2013 \\
\hline m1 (Z-statistic) & & $-5.74 * *$ & $-5.62 * *$ & $-5.79 * *$ & $-5.85^{* *}$ & $-5.66 * *$ & $-5.72 * *$ \\
\hline m2 (Z-statistic) & & 0.41 & 0.45 & 0.44 & 0.43 & 0.41 & 0.65 \\
\hline Hansen Test & & 0.42 & 0.17 & 0.25 & 0.17 & 0.43 & 0.22 \\
\hline
\end{tabular}

The dependent variable is the book value of equity to total assets ratio (CAPITAL). $\mathrm{m} 1$ and $\mathrm{m} 2$ are tests for first order and second order serial correlation in the first-differenced residuals, under the null of no serial correlation. The Hansen test is a test of the overidentifying restrictions, distributed as chi-square under the null of instrument validity. T-statistics based on asymptotic standard errors that are robust for heteroskedasticity and clustered by the banks are in the parentheses. *, and ** indicate coefficients' significance at $5 \%$, and $1 \%$ level, respectively. In the models, we include the year and country dummies, the bank- and country-level determinants of capital (described in Table A2 in Appendix A). For the sake of brevity, they are not presented.

\subsection{Other sensitivity tests}

In line with e.g., De Jonghe and Öztekin (2015), two alternative measures of a bank’s capital ratios are employed as a robustness check: tier 1 regulatory capital ratio, and total regulatory capital ratio. Second, to eliminate the influence of mergers, acquisitions, and divestitures on our results (Berger and Bouwman, 2009), we drop bank-year observations with substantial changes (plus/minus 20 percentage points or more) in banks’ total assets. Third, we bring five additional variables to all models, as in De Jonghe and Öztekin (2015): Stock Market Capitalization, banks' Cost to Income Ratio, Liquidity Ratio, Retail Funding Share and Net Interest Income Share. Finally, there are 68 banks and 850 bank-year observations from the U.S., corresponding to $17 \%$ and $21 \%$ of the entire sample, respectively. Therefore, we exclude the U.S. banks from our sample to tackle a potential over-representation bias 
(Wojewodzki et al., 2018). The results obtained from these models (available on request) remain largely unchanged.

\section{Conclusions}

This study investigates the associations between credit ratings and banks' capital ratio in a cross-country context which remains largely unexplored despite the growing research on this topic for non-financial firms in recent years. The lack of research is surprising given the importance of the fact that the information embedded in a credit rating constitutes a basis of customers' trust and confidence in a bank’s asset quality, profitability, stability and regulatory reforms (Millon and Thakor, 1985). Moreover, the assets and liabilities of banks (i.e., deposits and loans) are fundamentally different from those of non-financial firms (Fan et al., 2012). Importantly, banks' capital and investments in bonds are directly tied to credit ratings, making rating-embedded information important for banks' stability. Against this backdrop, the associations between credit ratings and banks' capital ratio must be examined. We do so by employing an analytical approach, namely a dynamic partial adjustment framework through the GMM Two-Step System estimator, capable of tackling endogeneity problems in the sample of 391 rated commercial banks from 76 countries spanning 15 years.

Out of seven credit rating effects previously documented in studies on non-financial firms, two are found to be statistically significant in our study. Specifically, the results indicate that banks near a credit rating upgrade have higher capital ratios compared to banks not near a rating upgrade. We call this association the "plus sign" effect of credit ratings. Interestingly, the "plus sign" effect turns out to be negative for the most systemically important cohort of banks. This indicates that the expected future gains stemming from the rating upgrade for most banks (less systemically important) outweigh the costs of increased capital ratios. However, the most 
systematically important, "too-big-to-fail" banks use credit ratings with a plus sign as a positive signal of being near a rating upgrade, to facilitate the reduction of their already low capital ratios, i.e., the "leverage ratchet effect". Furthermore, banks downgraded to a speculative-grade rating from an investment-grade rating (so-called fallen angels) hold less capital relative to assets. Such negative "fallen angel" effect of credit ratings highlights the importance of the border between investment- and speculative-grade ratings on banks’ capital. This can be related to various regulations and the "cliff effect" experienced by banks as a follow-up to falling into a speculative rating category.

Second, contrary to studies based on non-financial firms, we find evidence that although banks with lower credit ratings adjust to optimal capital ratios at a faster speed than banks with higher credit ratings, this difference is relatively small. The conclusion to be drawn here is that credit ratings appear to play a negligible role on the speed with which banks adjust their capital. This may be attributed to a lack of financial flexibility and/or the "leverage ratchet effect" of poorly rated banks. In conclusion, our results suggest that while rating agencies exert influences on banks' capital structure, these are fewer, in comparison with those established for non-financial firms. In other words, except for the "plus sign" and the "fallen angel” effects, credit ratings are not the first-order factor in banks' capital structure.

From a regulatory policy perspective, documented long-run "plus-sign" and "fallen angel" effects (1 and 3.2 percentage points, respectively) suggest that the $3 \%$ minimum leverage ratio set in the Basel III Accord is insufficient. Thus, we add to the choir of voices advocating a drastic increase in banks' capital and of Basel III's leverage ratio. These novel findings contribute by offering new empirical evidence to policymakers attempting to improve banking capital regulation. 
The main limitation of this research is data related. The limited presence of banks' credit ratings (in the earlier years of the investigation and for developing economies), may cause disparities in the number of observations and banks amongst countries and over time. Despite the new contributions of this study, more studies appear warranted. Future research should focus on an event-type of study investigating the relationship between credit ratings and banks' net issuance of equity vis-à-vis debt. Another avenue of research should explore the effects of credit ratings on both the numerator (equity) and denominator (total assets) of banks' capital ratios, in separation.

\section{References}

Abreu, J. F., and M. A. Gulamhussen. (2013). The stock market reaction to the public announcement of a supranational list of too-big-to-fail banks during the financial crisis. Journal of International Financial Markets, Institutions and Money, 25 (1), 49-72.

Adelino, M., and M. A. Ferreira. (2016). Bank ratings and lending supply: evidence from sovereign downgrades. Review of Financial Studies, 29 (7), 1709-1746.

Admati, A. R.; P. M. Demarzo; M. F. Hellwig; and P. Pfleiderer. (2018). The leverage ratchet effect. Journal of Finance, 73 (1), 145-198.

Admati, A. R., and M. F. Hellwig. (2019). Bank leverage, welfare and regulation. In Arner D., E. Avgouleas; D. Admati, A. R.; P. M. Demarzo; M. F. Hellwig; and P. Pfleiderer. (2018). The leverage ratchet effect. Journal of Finance, 73 (1), 145-198.

Adrian, T., and H. S. Shin. (2010). Liquidity and leverage. Journal of Financial Intermediation, 19 (3), 418-437.

Baghai, R. P.; H. Servaes; and A. Tamayo. (2014). Have rating agencies become more conservative? Implications for capital structure and debt pricing. Journal of Finance, 69 (5), 1961-2005.

Barth, J. R.; G. Caprio, and R. Levine. (2001). The regulation and supervision of banks around the world: A new database. Policy Research working paper no. WPS 2588. Washington, DC: World Bank.

Barth, J. R.; G. Caprio, and R. Levine. (2008). Bank regulations are changing: for better or worse? Comparative Economic Studies, 50 (4), 537-563.

Barth, J. R.; G. Caprio, and R. Levine. (2013). Bank regulation and supervision in 180 countries from 1999 to 2011. Journal of Financial Economic Policy, 5 (2), 111-219. 
Belkhir, M. (2013). Do subordinated debt holders discipline bank risk-taking? Evidence from risk management decisions. Journal of Financial Stability, 9 (4), 705-719.

Berger, A. N., and C. H. S. Bouwman. (2009). Bank liquidity creation. Review of Financial Studies, 22 (9), 3779-3837.

Berger, A. N.; R. De Young; M. J. Flannery; D. Lee; and Ö. Öztekin. (2008). How do large banking organizations manage their capital ratios? Journal of Financial Services Research, 34 (2), 123-149.

Billett, M. T.; J. A. Garfinkel; and E. S. O'Neal. (1998). The cost of market versus regulatory discipline in banking'. Journal of Financial Economics, 48 (3). 333-358.

Blume, M.; F. Lim; and C. Mackinlay. (1988). The declining credit quality of US corporate debt: myth or reality? Journal of Finance, 53 (4), 1389-1413.

Blundell, R., and S. Bond. (1998). Initial conditions and moment restrictions in dynamic panel data models. Journal of Econometrics, 87 (1), 115-143.

Costello, M., and D. Sabbagh. (2009). Moody's and S\&P berated as Reed taps its investors. The Times [online]. 31 July. Accessed March 9, 2018. https://www.thetimes.co.uk/article/moodys-and-sandp-berated-as-reed-taps-its-investors-m90 $\underline{\text { khrltdc7 }}$

Crabbe, L. E.; and M. A. Post (1994). The effect of a rating downgrade on outstanding commercial paper. Journal of Finance, 49 (1), 39-56.

Deb, P.; M. Manning; G. Murphy; A. Penalver; and A. Toth. (2011). Whither the credit ratings industry? Bank of England, Financial Stability Paper No. 9, 1-22.

De Jonghe, O. G., and O. Öztekin. (2015). Bank capital management: international evidence. Journal of Financial Intermediation, 24 (2), 154-177.

Demirgüç-Kunt, A.; E. Kane, and L. Laeven. (2015). Deposit insurance around the world: a comprehensive analysis and database. Journal of Financial Stability, 20, 155-183.

de Mooij, R. A., and M. Keen. (2016). Debt, taxes, and banks. Journal of Money, Credit and Banking, 48 (1), 5-33.

Diamond, D. W., and R. G. Rajan. (2000). A theory of bank capital, Journal of Finance, 55 (6), 2431-2465.

Estrella, A. (2000). Credit ratings and complementary sources of credit quality information. Basel Committee on banking supervision (BCBS), Working Paper 3. Accessed August 28, 2020. https://www.bis.org/publ/bcbs_wp3.htm

European Central Bank (ECB) (2008). Financial Stability Review, December 2008.

European Parliament. (2009). Regulation of European and of the council of credit rating 
agencies, Brussels.

European Securities Market Expert Group. (2008). Role of credit rating agencies, ESME's report to the European Commission, Brussels.

Fan, J. P. H.; S. Titman; and G. Twite. (2012). An international comparison of capital structure and debt maturity choices. Journal of Financial and Quantitative Analysis, 47 (1), 23-56.

Ferri, G.; L. G. Liu, and J. E. Stiglitz. (1999). The procyclical role of rating agencies: evidence from the East Asian crisis. Economic Notes, 28 (3), 335-355.

Financial Services Authority. (2009). The Turner Review: a regulatory response to the global banking crisis, London.

Fitch Ratings, (2018). Rating Definitions.

Flannery, M. J., and K. W. Hankins. (2013). Estimating dynamic panel models in corporate finance. Journal of Corporate Finance, 19, 1-19.

Flannery, M. J., and M. Sorescu. (1996). Evidence of bank market discipline in subordinated debenture yields: 1983- 1991, Journal of Finance, 51 (4), 1347-1377.

Frank, M. Z., and V. K. Goyal. (2009). Capital structure decisions: which factors are reliably important? Financial Management, 38 (1), 1-37.

Graham, J. R., and C. R. Harvey. (2001). The theory and practice of corporate finance: Evidence from the field. Journal of Financial Economics, 60 (2), 187-243.

Griffin, J. M., and D. Y. Tang. (2011). Did credit rating agencies make unbiased assumptions on CDOs? American Economic Review, 101 (3), 125-130.

Gropp, R., and F. Heider. (2010). The determinants of bank capital structure. Review of Finance, 14 (4), 587-622.

Gu, G. W.; R. A. de Mooij; and T. Poghosyan. (2015). Taxation and leverage in international banking. International Tax and Public Finance, 22 (2), 177-200.

Gu, X.; P. Kadiyala; and X. W. Mahaney-Walter. (2018). How creditor rights affect the issuance of public debt: the role of credit ratings. Journal of Financial Stability, 39, 133-143.

Hau, H.; S. Langfield; and D. Marques-Ibanez. (2013). Bank ratings: what determines their quality? Economic Policy, 28 (74), 289-333.

Houston, J. F.; C. Lin, P. Lin; and Y. Ma. (2010). Creditor rights, information sharing, and bank risk taking. Journal of Financial Economics, 96 (3), 485-512.

Huang, Y.-L., and C.-H. Shen. (2015). Cross-country variations in capital structure adjustment: The role of credit ratings. International Review of Economics and Finance, 39, 277-294.

Iwarere, H. T., and G. T. Akinleye. (2010). Capital structure determinants in the Nigerian 
banking industry: financial managers’ perspectives. Pakistan Journal of Social Sciences, 7 (3), 205-213.

Jackson, P.; C. Furfine; H. Groeneveld; D. Hancock; D. Jones; W. Perraudin; L. Radecki; and M. Yoneyama. (1999). Capital requirements and bank behaviour: the impact of the Basel Accord. Basel Committee on Banking Supervision, Bank for International Settlements, Working Paper No.1, April 1999.

Kisgen, D. J. (2006). Credit ratings and capital structure. Journal of Finance, 61 (3), 1035-1072.

Kisgen, D. J. (2009). Do firms target credit ratings or leverage levels? Journal of Financial and Quantitative Analysis, 44 (6), 1323-1344.

Kisgen, D. J. (2019). The impact of credit ratings on corporate behavior: Evidence from Moody's adjustments. Journal of Corporate Finance, 58, 567-582.

Kisgen, D. J., and P. E. Strahan. (2010). Do regulations based on credit ratings affect a firm's cost of capital? The Review of Financial Studies, 23 (12), p. 4324-4347.

Kolaric, S; F. Kiesel; and S. R. G. Ongena. (2019). Market discipline through credit ratings and too-big-to-fail in banking. Swiss Finance Institute Research Paper. Social Science Research Network (SSRN). Accessed February 20, 2020.

https://papers.ssrn.com/sol3/papers.cfm?abstract_id=2928113

Korajczyk, R. A., and A. Levy. (2003). Capital structure choice: Macroeconomic conditions and financial constraints. Journal of Financial Economics, 68 (1), 75-109.

Laeven, L., and F. Valencia. (2018). Systemic banking crises revisited. IMF Working Papers 18/206, International Monetary Fund.

Lemmon, M., and M. R. Roberts. (2010). The response of corporate financing and investment to changes in the supply of credit. Journal of Financial and Quantitative Analysis, 45 (03), $555-587$.

Liu, Y., and P. Malatesta. (2005). Credit ratings and the pricing of seasoned equity offerings. Working Paper, University of Washington.

Maung, M., and R. H. Chowdhury. (2014). Credit rating changes and leverage adjustments: concurrent or continual? Review of Pacific Basin Financial Markets and Policies, 17 (4), $1-29$.

Memmel, C., and P. Raupach. (2010). How do banks adjust their capital ratios? Journal of Financial Intermediation, 19, 509-528.

Mishkin, F. S. (2000). The economics of money, banking and financial markets. Addison Wesley, New York.

Morgan, D. P. (2002). Rating banks: risk and uncertainty in an opaque industry. American Economic Review, 92, 874-888. 
Millon, M. H., and A. V. Thakor. (1985). Moral hazard and information sharing: a model of financial information gathering agencies, Journal of Finance, 40 (5), 1403-1422.

Opp, C. C.; M. M. Opp; and M. Harris. (2013). Rating agencies in the face of regulation. Journal of Financial Economics, 108 (1), 46-61.

Richards, A., and D. Deddouche. (2003). Bank rating changes and bank stock returns. Puzzling evidence from the emerging markets. Journal of Emerging Market Finance, 2 (3), 337-363.

Roodman, D. (2009). A Note on the theme of too many instruments. Oxford Bulletin of Economics and Statistics, 71 (1), 135-158.

Samaniego-Medina, R., and F. di Pietro. (2019). Rating and capital structure: How do the signs the speed of adjustment, Journal of International Financial Management and Accounting, 30 (3), 188-202.

Schweitzer, R.; S. Szewczyk; and R. Varma. (1992). Bond rating agencies and their role in bank market discipline. Journal of Financial Services Research, 6 (3), 249-263.

Servaes, H., and P. Tufano. (2006). Corporate capital structure. The theory and practice of corporate capital structure. Deutsche Bank, Liability Strategies Group, January, 1-89.

Sironi, A. (2003). Testing for market discipline in the European banking industry: evidence from subordinated debt issues. Journal of Money, Credit and Banking, 35 (3), 443-472.

S\&P Global Ratings. (S\&P). (2019). S\&P Global ratings definitions. September 18, 2019.

Stolz, S., and M. Wedow. (2011). Banks' regulatory capital buffer and the business cycle: Evidence for Germany. Journal of Financial Stability, 7 (2), 98-110.

Sufi, A. (2009). The real effects of debt certification: evidence from the introduction of bank loan ratings. Review of Financial Studies, 22 (4), 1659-1691.

Tadesse, S. (2006). Innovation, information, and financial architecture. Journal of Financial and Quantitative Analysis, 41 (4) 753-786.

Tang, T. T. (2009). Information asymmetry and firms' credit market access: Evidence from Moody’s credit rating format refinement. Journal of Financial Economics, 93 (2), 325-351.

Ueda, K., and B. W. di Mauro. (2013). Quantifying structural subsidy values for systemically important financial institutions. Journal of Banking and Finance, 37 (10), 3830-3842.

White, L. J. (2019). The credit rating agencies and their role in the financial system. In: Brousseau, E.; J-M. Glachant; and J. Sgard., ed. The Oxford Handbook of Institutions of International Economic Governance and Market Regulation. 1st ed.: Oxford University Press 
Wojewodzki, M; W. P. H. Poon; and J. Shen. (2018). The role of credit ratings on capital structure and its speed of adjustment: an international study. European Journal of Finance, 24 (9), 735-760.

\section{Appendix A}

Table A1

List of countries covered in the sample with frequency (and percentage share) of banks and observations per country.

\begin{tabular}{|c|c|c|c|c|c|c|c|c|c|}
\hline Country & \multicolumn{2}{|c|}{ Observations } & \multicolumn{2}{|c|}{ Banks } & Country & \multicolumn{2}{|c|}{ Observations } & \multicolumn{2}{|c|}{ Banks } \\
\hline Argentina & 8 & $0.20 \%$ & 1 & $0.26 \%$ & Kazakhstan & 51 & $1.27 \%$ & 4 & $1.02 \%$ \\
\hline Australia & 65 & $1.62 \%$ & 8 & $2.05 \%$ & Kenya & 5 & $0.12 \%$ & 1 & $0.26 \%$ \\
\hline Austria & 37 & $0.92 \%$ & 4 & $1.02 \%$ & Kuwait & 50 & $1.24 \%$ & 4 & $1.02 \%$ \\
\hline Azerbaijan & 43 & $1.07 \%$ & 6 & $1.53 \%$ & Lebanon & 28 & $0.70 \%$ & 2 & $0.51 \%$ \\
\hline Bahrain & 60 & $1.49 \%$ & 5 & $1.28 \%$ & Luxembourg & 18 & $0.45 \%$ & 2 & $0.51 \%$ \\
\hline Belarus & 9 & $0.22 \%$ & 1 & $0.26 \%$ & Масао & 10 & $0.25 \%$ & 1 & $0.26 \%$ \\
\hline Belgium & 36 & $0.89 \%$ & 4 & $1.02 \%$ & Mexico & 87 & $2.16 \%$ & 8 & $2.05 \%$ \\
\hline Brazil & 124 & $3.08 \%$ & 15 & $3.84 \%$ & Morocco & 7 & $0.17 \%$ & 1 & $0.26 \%$ \\
\hline Bulgaria & 22 & $0.55 \%$ & 3 & $0.77 \%$ & Netherlands & 39 & $0.97 \%$ & 5 & $1.28 \%$ \\
\hline Canada & 11 & $0.27 \%$ & 1 & $0.26 \%$ & New Zealand & 31 & $0.77 \%$ & 4 & $1.02 \%$ \\
\hline Chile & 11 & $0.27 \%$ & 2 & $0.51 \%$ & Nigeria & 10 & $0.25 \%$ & 2 & $0.51 \%$ \\
\hline China & 38 & $0.94 \%$ & 4 & $1.02 \%$ & Norway & 9 & $0.22 \%$ & 1 & $0.26 \%$ \\
\hline Colombia & 17 & $0.42 \%$ & 2 & $0.51 \%$ & Oman & 41 & $1.02 \%$ & 3 & $0.77 \%$ \\
\hline Costa Rica & 7 & $0.17 \%$ & 1 & $0.26 \%$ & Panama & 7 & $0.17 \%$ & 1 & $0.26 \%$ \\
\hline Croatia & 14 & $0.35 \%$ & 1 & $0.26 \%$ & Peru & 21 & $0.52 \%$ & 3 & $0.77 \%$ \\
\hline Cyprus & 26 & $0.65 \%$ & 2 & $0.51 \%$ & Philippines & 38 & $0.94 \%$ & 5 & $1.28 \%$ \\
\hline Czech Republic & 28 & $0.70 \%$ & 2 & $0.51 \%$ & Poland & 66 & $1.64 \%$ & 7 & $1.79 \%$ \\
\hline Denmark & 19 & $0.47 \%$ & 2 & $0.51 \%$ & Portugal & 28 & $0.70 \%$ & 3 & $0.77 \%$ \\
\hline Dominican Republic & 18 & $0.45 \%$ & 2 & $0.51 \%$ & Qatar & 30 & $0.75 \%$ & 3 & $0.77 \%$ \\
\hline Ecuador & 13 & $0.32 \%$ & 1 & $0.26 \%$ & Romania & 36 & $0.89 \%$ & 3 & $0.77 \%$ \\
\hline Egypt, Arab Rep. & 22 & $0.55 \%$ & 2 & $0.51 \%$ & Russian Federation & 134 & $3.33 \%$ & 15 & $3.84 \%$ \\
\hline El Salvador & 32 & $0.80 \%$ & 3 & $0.77 \%$ & Saudi Arabia & 101 & $2.51 \%$ & 8 & $2.05 \%$ \\
\hline Finland & 19 & $0.47 \%$ & 2 & $0.51 \%$ & Singapore & 29 & $0.72 \%$ & 3 & $0.77 \%$ \\
\hline France & 121 & $3.01 \%$ & 13 & $3.32 \%$ & Slovak Republic & 14 & $0.35 \%$ & 1 & $0.26 \%$ \\
\hline Georgia & 38 & $0.94 \%$ & 4 & $1.02 \%$ & Slovenia & 62 & $1.54 \%$ & 4 & $1.02 \%$ \\
\hline Germany & 111 & $2.76 \%$ & 11 & $2.81 \%$ & South Africa & 35 & $0.87 \%$ & 4 & $1.02 \%$ \\
\hline Greece & 40 & $0.99 \%$ & 4 & $1.02 \%$ & Spain & 30 & $0.75 \%$ & 3 & $0.77 \%$ \\
\hline Guatemala & 8 & $0.20 \%$ & 1 & $0.26 \%$ & Sweden & 18 & $0.45 \%$ & 2 & $0.51 \%$ \\
\hline Hong Kong & 68 & $1.69 \%$ & 7 & $1.79 \%$ & Switzerland & 33 & $0.82 \%$ & 3 & $0.77 \%$ \\
\hline Hungary & 28 & $0.70 \%$ & 2 & $0.51 \%$ & Thailand & 105 & $2.61 \%$ & 9 & $2.30 \%$ \\
\hline India & 32 & $0.80 \%$ & 4 & $1.02 \%$ & Tunisia & 10 & $0.25 \%$ & 1 & $0.26 \%$ \\
\hline Indonesia & 101 & $2.51 \%$ & 10 & $2.56 \%$ & Turkey & 158 & $3.93 \%$ & 16 & $4.09 \%$ \\
\hline Ireland & 18 & $0.45 \%$ & 2 & $0.51 \%$ & Ukraine & 32 & $0.80 \%$ & 3 & $0.77 \%$ \\
\hline Israel & 28 & $0.70 \%$ & 2 & $0.51 \%$ & United Arab Emirates & 87 & $2.16 \%$ & 8 & $2.05 \%$ \\
\hline Italy & 67 & $1.67 \%$ & 8 & $2.05 \%$ & United Kingdom & 199 & $4.95 \%$ & 22 & $5.63 \%$ \\
\hline Jamaica & 8 & $0.20 \%$ & 1 & $0.26 \%$ & United States & 850 & $21.12 \%$ & 68 & $17.39 \%$ \\
\hline Japan & 52 & $1.29 \%$ & 6 & $1.53 \%$ & Uruguay & 22 & $0.55 \%$ & 2 & $0.51 \%$ \\
\hline Jordan & 23 & $0.57 \%$ & 2 & $0.51 \%$ & Venezuela, RB & 71 & $1.76 \%$ & 5 & $1.28 \%$ \\
\hline
\end{tabular}

Total

4,024 391

Due to a self-imposed minimum of 5 consecutive observations per bank, with no missing variables, there are 15 , 17, 11 and 11 countries represented by just one, two, three and four banks, respectively. The final sample is an unbalanced panel of 4,024 bank-year observations spanning across 76 countries and 15-year period (1998-2013). 
Table A2

Bank-specific, credit rating-related, macroeconomic and regulatory variables

\begin{tabular}{|c|c|c|c|}
\hline Name & Variable & $\begin{array}{l}\text { Definition/Corresponding Bankscope item } \\
\text { codes }\end{array}$ & Data Source \\
\hline \multicolumn{4}{|l|}{$\begin{array}{l}\text { Dependent } \\
\text { variable }\end{array}$} \\
\hline CAPITAL & $\begin{array}{l}\text { Equity to total assets } \\
\text { ratio }\end{array}$ & $\begin{array}{l}\text { Equity/total assets } * 100 \text { winsorised at the } 1 \text { st } \\
\text { and 99th percentile; data } 4009= \\
\text { data2055/data2060*100 }\end{array}$ & Bankscope \\
\hline \multicolumn{4}{|l|}{$\begin{array}{l}\text { Bank-specific } \\
\text { variables }\end{array}$} \\
\hline SIZE & $\ln$ (total assets) & $\begin{array}{l}\text { Natural logarithm of total annual assets } \\
\text { measured in USD and winsorised at the 1st } \\
\text { and 99th percentile. }\end{array}$ & $\begin{array}{l}\text { Bankscope } \\
\text { Datastream }\end{array}$ \\
\hline$R O A A$ & $\begin{array}{l}\text { Return on average } \\
\text { assets }\end{array}$ & $\begin{array}{l}\text { Net income/(total assets }(\mathrm{t})+\text { total } \\
\text { assets }(\mathrm{t}-1)) / 2 \text {, winsorised at the } 1 \text { st and } 99 \text { th } \\
\text { percentile; data4024 = } \\
\text { data2115/data2025AVG*100 }\end{array}$ & Bankscope \\
\hline RISK & $\begin{array}{l}\text { Loan loss provisions } \\
\text { to net loans ratio }\end{array}$ & $\begin{array}{l}\text { Loan loss provisions/net loans*100, } \\
\text { winsorised at the } 1 \text { st and 99th percentile; } \\
\text { data2095/data2000*100 }\end{array}$ & \\
\hline \multicolumn{4}{|l|}{$\begin{array}{l}\text { Credit } \\
\text { rating-related } \\
\text { variables }\end{array}$} \\
\hline RATING & $\begin{array}{l}\text { Bank's Long-Term } \\
\text { Issuer Default Rating } \\
\text { (IDF) issued by Fitch } \\
\text { rating agency }\end{array}$ & $\begin{array}{l}\text { Original letter-coded credit ratings are } \\
\text { transformed by assigning ordinal integers } \\
\text { from } 1 \text { for the highest rating (AAA), to } 19 \text { for } \\
\text { the lowest rating (CC). }\end{array}$ & Bankscope \\
\hline JUNK & $\begin{array}{l}\text { Non-investment-grade } \\
\text { dummy }\end{array}$ & $\begin{array}{l}\text { Equals one if a bank has a } \\
\text { non-investment-grade credit rating (coded as } \\
\text { BB+ and below) and zero otherwise (BBB-- } \\
\text { rating or above). }\end{array}$ & Bankscope \\
\hline DOWNGRD & $\begin{array}{l}\text { Credit rating } \\
\text { downgrade dummy }\end{array}$ & $\begin{array}{l}\text { Equals one if a bank's credit rating has been } \\
\text { downgraded in a current year (t) compared to } \\
\text { the previous year (t-1) and zero otherwise. }\end{array}$ & Bankscope \\
\hline UPGRD & $\begin{array}{l}\text { Credit rating upgrade } \\
\text { dummy }\end{array}$ & $\begin{array}{l}\text { Equals one if a bank's credit rating is } \\
\text { upgraded in a current year }(\mathrm{t}) \text { compared to the } \\
\text { previous year }(\mathrm{t}-1) \text { and zero otherwise. }\end{array}$ & Bankscope \\
\hline CRMINUS & $\begin{array}{l}\text { Minus sign credit } \\
\text { rating dummy }\end{array}$ & $\begin{array}{l}\text { Equals one if a bank has a credit rating with a } \\
\text { minus sign and zero otherwise. }\end{array}$ & Bankscope \\
\hline CRPLUS & $\begin{array}{l}\text { Plus sign credit rating } \\
\text { dummy }\end{array}$ & $\begin{array}{l}\text { Equals one if a bank has a credit rating with a } \\
\text { plus sign and zero otherwise. }\end{array}$ & Bankscope \\
\hline$P O M$ & $\begin{array}{l}\text { Either minus or plus } \\
\text { sign credit rating } \\
\text { dummy }\end{array}$ & $\begin{array}{l}\text { Equals one if a bank has a credit rating with } \\
\text { either a minus or a plus sign and zero } \\
\text { otherwise. }\end{array}$ & Bankscope \\
\hline FALLEN & $\begin{array}{l}\text { Credit rating } \\
\text { downgrade (from } \\
\text { investment-grade to } \\
\text { non-investment grade) } \\
\text { dummy }\end{array}$ & $\begin{array}{l}\text { Equals one if a bank's credit rating has been } \\
\text { downgraded (from an investment-grade to a } \\
\text { non-investment-grade) in a current year (t) } \\
\text { compared to the previous year (t-1) and zero } \\
\text { otherwise. }\end{array}$ & Bankscope \\
\hline
\end{tabular}


Table A2 (Continued)

\begin{tabular}{|c|c|c|c|}
\hline Name & Variable & Definition & Data Source \\
\hline \multicolumn{4}{|l|}{$\begin{array}{l}\text { Macroeconomic } \\
\text { variables }\end{array}$} \\
\hline INFL & $\begin{array}{l}\text { Annual inflation } \\
\text { rate }\end{array}$ & $\begin{array}{l}\text { Inflation measured by annual growth rate of } \\
\text { country-specific Consumer Price Index } \\
(\mathrm{CPI}(\mathrm{t}) \text { - CPI(t-1))/CPI(t-1)*100 }\end{array}$ & World Bank \\
\hline CRISIS & $\begin{array}{l}\text { Systemic banking } \\
\text { crisis dummy }\end{array}$ & $\begin{array}{l}\text { equals one if, in a given year, a country } \\
\text { underwent a systemic banking crisis and } \\
\text { zero otherwise. }\end{array}$ & $\begin{array}{l}\text { Laeven and Valencia } \\
\text { (2018) }\end{array}$ \\
\hline GDPGROW & $\begin{array}{l}\text { Gross domestic } \\
\text { product (GDP) } \\
\text { growth }\end{array}$ & $\begin{array}{l}\text { The annual growth rate of GDP at market } \\
\text { prices based on constant local currency. }\end{array}$ & World Bank \\
\hline GDPPERCAP & $\begin{array}{l}\text { GDP per capita } \\
\text { (current USD) }\end{array}$ & $\begin{array}{l}\text { GDP per capita is gross domestic product } \\
\text { divided by the mid-year population. Data are } \\
\text { in current USD. }\end{array}$ & World Bank \\
\hline \multicolumn{4}{|l|}{$\begin{array}{l}\text { Regulatory } \\
\text { variables }\end{array}$} \\
\hline$C A P \_R E G$ & $\begin{array}{l}\text { Capital regulatory } \\
\text { index }\end{array}$ & $\begin{array}{l}\text { A composite index based on questions 1.4.2, } \\
\text { 1.4.3, 1.5, 3.1(a), 3.2(a), 3.2(b), 3.18.2, } \\
\text { 3.18.3(d) from Banking Regulation and } \\
\text { Supervision Database. The index can take } \\
\text { any integer from zero to ten such that the } \\
\text { larger the value, the greater stringency of } \\
\text { capital regulation in a given country and } \\
\text { year. Similar to Gu et al. (2015), we assign } \\
\text { data for years (corresponding to four surveys } \\
\text { used to compile Regulation and Supervision } \\
\text { Database): 1999, 2002, 2005 and 2010 to } \\
\text { periods of 1998-2001, 2002-2004, 2005- } \\
\text { 2007, and 2008-2013, respectively. I.e., We } \\
\text { use the last available year as a proxy for } \\
\text { years with a missing value. }\end{array}$ & $\begin{array}{l}\text { Barth et al. (2001, } \\
\text { 2008, 2013) }\end{array}$ \\
\hline SUPERV & $\begin{array}{l}\text { Official } \\
\text { supervisory power } \\
\text { index }\end{array}$ & $\begin{array}{l}\text { A composite index based on questions } \\
\text { 5.12(b), 10.5(b), 11.1(f, j, k), 11.5(a, b, c), } \\
\text { 12.3.2 from Banking Regulation and } \\
\text { Supervision Database. The index can take } \\
\text { any integer from zero to thirteen such that } \\
\text { the larger the number, the more independent } \\
\text { is country’s banking supervisory authority } \\
\text { and the more monitoring and disciplinary } \\
\text { powers there are at its disposal in a given } \\
\text { year. Similar to Gu et al. (2015), we assign } \\
\text { data for years (corresponding to four surveys } \\
\text { used to compile Regulation and Supervision } \\
\text { Database): 1999, 2002, 2005 and 2010 to } \\
\text { periods of 1998-2001, 2002-2004, } 2005- \\
\text { 2007, and 2008-2013, respectively. I.e., we } \\
\text { use the last available year as a proxy for } \\
\text { years with a missing value. }\end{array}$ & $\begin{array}{l}\text { Barth et al. (2001, } \\
\text { 2008, 2013) }\end{array}$ \\
\hline
\end{tabular}


Table A2 (Continued)

\begin{tabular}{|c|c|c|c|}
\hline Name & Variable & Definition & Data Source \\
\hline$P R I V \_M O N$ & $\begin{array}{l}\text { Private } \\
\text { monitoring power } \\
\text { index }\end{array}$ & $\begin{array}{l}\text { A composite index based on questions 5.1, } \\
\text { 5.1.1(a), 10.1, 10.2.5, 10.5.1(b, c), 10.5.2, } \\
10.8 \text { from Banking Regulation and } \\
\text { Supervision Database. The index can take } \\
\text { any integer from zero to thirteen eight, such } \\
\text { that the larger the integer, the stronger the } \\
\text { empowerment of financial markets to } \\
\text { monitor banks in a given country and year. } \\
\text { Similar to Gu et al. (2015), we assign data } \\
\text { for years (corresponding to four surveys } \\
\text { used to compile Regulation and Supervision } \\
\text { Database): 1999, 2002, 2005 and 2010 to } \\
\text { periods of 1998-2001, 2002-2004, 2005- } \\
\text { 2007, and 2008-2013, respectively. I.e., we } \\
\text { use the last available year as a proxy for } \\
\text { years with a missing value. }\end{array}$ & $\begin{array}{l}\text { Barth et al. (2001, 2008, } \\
\text { 2013) }\end{array}$ \\
\hline EDIS & $\begin{array}{l}\text { Explicit deposit } \\
\text { scheme dummy }\end{array}$ & $\begin{array}{l}\text { Equals to one for those years during which } \\
\text { in a given country existed explicit deposit } \\
\text { insurance scheme and zero otherwise. }\end{array}$ & $\begin{array}{l}\text { Demirgüç-Kunt et al. } \\
\text { (2015) }\end{array}$ \\
\hline $\begin{array}{l}\text { Robustness } \\
\text { Tests variables } \\
\end{array}$ & & & \\
\hline TBTF_5 & $\begin{array}{l}\text { Dummy variable } \\
\text { proxying for } \\
\text { systemically } \\
\text { important } \\
\text { "too-big-to-fail" } \\
\text { banks }\end{array}$ & $\begin{array}{l}\text { Equals one if a bank's total assets constitute } \\
50 \% \text { or more of the country's annual GDP, } \\
\text { and zero otherwise. }\end{array}$ & $\begin{array}{l}\text { Bankscope } \\
\text { World Bank }\end{array}$ \\
\hline TBTF_25 & $\begin{array}{l}\text { Dummy variable } \\
\text { proxying for } \\
\text { systemically } \\
\text { important } \\
\text { "too-big-to-fail" } \\
\text { banks }\end{array}$ & $\begin{array}{l}\text { Equals one if a bank's total assets constitute } \\
25 \% \text { or more of the country's annual GDP, } \\
\text { and zero otherwise. }\end{array}$ & $\begin{array}{l}\text { Bankscope } \\
\text { World Bank }\end{array}$ \\
\hline FINARCH & $\begin{array}{l}\text { Financial } \\
\text { Architecture }\end{array}$ & $\begin{array}{l}\text { The first principal component of three } \\
\text { indices measuring the country's financial } \\
\text { system orientation based on the relative size, } \\
\text { activity, and efficiency of stock markets } \\
\text { vis-à-vis the banking sector. The higher is } \\
\text { the value of FINARCH, the more } \\
\text { market-oriented is the financial system of a } \\
\text { country. } \\
\text { - The relative size index: [(market } \\
\text { capitalization of domestic stocks / GDP) / } \\
\text { claims of the banking sector against the } \\
\text { private real sector / GDP)] } \\
\text { - The relative efficiency index: [(total value } \\
\text { of shares traded /average real market } \\
\text { capitalization)* (banking overhead costs / } \\
\text { banking assets)] }\end{array}$ & World Bank \\
\hline
\end{tabular}


- The relative activity index: [(total value of shares traded / GDP) / (claims of the banking sector against the private real sector / GDP)]

This table lists dependent and independent variables used in the regression analyses. The Name column quotes the exact names of the variables corresponding to the mentioned characteristics. The Variable column provides succinct definitions of the variables. The Definition/Corresponding Bankscope Data Codes column describes calculations/procedures performed to obtain the variables, and in case of CAPITAL, SIZE, ROAA and RISK variable, offers corresponding data codes from the Bankscope database. The Data Source column provides databases from which we obtained variables used in regression analyses. 